NBER WORKING PAPER SERIES

\title{
STATE INCENTIVES FOR INNOVATION, STAR SCIENTISTS AND JOBS: EVIDENCE FROM BIOTECH
}

\author{
Enrico Moretti \\ Daniel J. Wilson \\ Working Paper 19294 \\ http://www.nber.org/papers/w19294
NATIONAL BUREAU OF ECONOMIC RESEARCH
1050 Massachusetts Avenue
Cambridge, MA 02138

August 2013

We are grateful to Tim Bartik, the editor and two referees for useful suggestions. Katherine Kuang, Timothy Ni, and Lauren Ford provided excellent research assistance. Moretti thanks the Innovation Policy working group at the NBER, the W.E. Upjohn Institute for Employment Research and Microsoft for generous support. The views expressed in this paper represent those of the authors alone and do not necessarily represent the views of the Federal Reserve Bank of San Francisco, the Federal Reserve System, or the National Bureau of Economic Research.

NBER working papers are circulated for discussion and comment purposes. They have not been peerreviewed or been subject to the review by the NBER Board of Directors that accompanies official NBER publications.

(C) 2013 by Enrico Moretti and Daniel J. Wilson. All rights reserved. Short sections of text, not to exceed two paragraphs, may be quoted without explicit permission provided that full credit, including $\odot$ notice, is given to the source. 
State Incentives for Innovation, Star Scientists and Jobs: Evvidence from Biotech

Enrico Moretti and Daniel J. Wilson

NBER Working Paper No. 19294

August 2013

JEL No. H0,J0,R0

\begin{abstract}
$\underline{\text { ABSTRACT }}$
We evaluate the effects of state-provided financial incentives for biotech companies, which are part of a growing trend of placed-based policies designed to spur innovation clusters. We estimate that the adoption of subsidies for biotech employers by a state raises the number of star biotech scientists in that state by about 15 percent over a three year period. A $10 \%$ decline in the user cost of capital induced by an increase in R\&D tax incentives raises the number of stars by $22 \%$. Most of the gains are due to the relocation of star scientist to adopting states, with limited effect on the productivity of incumbent scientists already in the state. The gains are concentrated among private sector inventors. We uncover little effect of subsidies on academic researchers, consistent with the fact that their incentives are unaffected. Our estimates indicate that the effect on overall employment in the biotech sector is of comparable magnitude to that on star scientists. Consistent with a model where workers are fairly mobile across states, we find limited effects on salaries in the industry. We uncover large effects on employment in the non-traded sector due to a sizable multiplier effect, with the largest impact on employment in construction and retail. Finally, we find mixed evidence of a displacement effect on states that are geographically close, or states that economically close as measured by migration flows.
\end{abstract}

\author{
Enrico Moretti \\ University of California, Berkeley \\ Department of Economics \\ 549 Evans Hall \\ Berkeley, CA 94720-3880 \\ and NBER \\ moretti@econ.berkeley.edu \\ Daniel J. Wilson \\ Federal Reserve Bank of San Francisco \\ 101 Market St. \\ Mail Stop 1130 \\ San Francisco, CA 94105-1530 \\ Daniel.Wilson@sf.frb.org
}




\section{Introduction}

There is growing empirical evidence that agglomeration of economic activity generates significant economies of scale at the local level. This evidence raises both normative questions, concerning whether government intervention is socially optimal from a national or global perspective, and positive questions about whether such intervention, even if desirable, is effective. Can firms' location decisions be influenced by government incentives and, if so, should national or local governments provide incentives to firms to cluster in particular locations?

These questions have led to growing interest among economists on the effect of place-based economic policies. Place-based economic policies are development strategies intended to foster economic activity in a city or a region. These policies are widespread both in the US and in the rest of the world. ${ }^{1}$ Indeed, it is rare for a large production or research facility to open today in the US without the provision of some form of subsidy from the relevant local government (Greenstone and Moretti, 2004; Greenstone, Hornbeck and Moretti, 2010.)

An increasingly common type of place-based policy is state-provided subsidies for "hightech" and life-science firms designed to spur innovation-based clusters. Urban economists have long suspected that innovative industries like high-tech and life-science are characterized by significant localized agglomeration economies. For example, the distribution of the biotechnology industry is heavily clustered spatially, with a large fraction of the industry employment concentrated in Boston/Cambridge, the San Francisco Bay area, San Diego, New Jersey, Raleigh-Durham and the Washington, D.C. area. This concentration is consistent with the existence of strong localized agglomeration externalities. ${ }^{2}$

\footnotetext{
${ }^{1}$ Bartik's seminal book on place-based economic policies (1991) provides a comprehensive taxonomy and discussion of the different types of policies. In the US, state and local governments spend $\$ 80$ billion per year on these policies (Story, 2013), while the federal government spends $\$ 15$ billion (GAO, 2012). Examples of locationbased policies typically adopted by local and state governments include direct subsidies and/or tax incentives for local firms, subsidized loans, industrial parks, technology transfer programs, export assistance and export financing, the provision of infrastructure, and workforce training.

${ }^{2}$ The hypothesis of agglomeration economies dates back at least to Marshall (1920) who discussed how they could be generated by a variety of mechanisms, including localized knowledge spillovers, thick labor markets for specialized workers, and localized supply chains.
} 
Because local governments often aim at creating and fostering self-sustaining clusters of lifescience research, a growing number of them have introduced incentives that specifically target the biotech industry. As of 2010, 11 states provide some type of incentive for biotech firms, and their generosity appears to be growing. In addition, over the past two decades, general R\&D tax credits offered by U.S. states have become increasingly important. These credits are not specific to biotech, but given the importance of R\&D for the industry they are likely to disproportionally benefit the biotech sector. As of 2010, 34 states provide a broad-based tax credit on R\&D, and the average effective credit rate has grown approximately four-fold over this period to equal half the value of the federal effective credit rate. In many states, the state tax credit is considerably more generous than the federal credit (Wilson 2009).

Yet, despite the growing importance of these incentives, their effects are not well understood. $^{3}$ In this paper, we investigate the effects of state-provided biotech incentives on the local biotech industry and the broader state economy. We construct a rich state-level panel data set combining data on biotech-specific incentives and general R\&D tax credits with data on various outcomes measuring biotech activity in a given state and year. Our outcome measures consist of the number of "star scientists" (defined below), employment, wages, establishments and patents - each specific to the biotech sector - for the period 1990-2010. We also estimate models where the outcome variables measure employment in the non-traded sector outside biotech. Using this data set, we identify the effect of biotech incentives and the R\&D user cost off of the variation within each state over time.

We find significant effects both of the biotech specific subsidies and the general R\&D tax credits on biotech star scientists, defined as those patenters whose patent count over the previous ten years is in the top $5 \%$ of patenters nationally. ${ }^{4}$ The adoption of biotech subsidies raises the

\footnotetext{
${ }^{3}$ Economists have long cautioned that due to the complex nature of the market failures at work it is unclear what cluster policies should do in practice and how they should do it (Duranton, 2011). A number of recent empirical studies have sought to assess the effectiveness of state-wide incentives. Examples include, but are not limited to, Faulk (2002), Bartik and Erickcek (2010), Bartik and Eberts (2012), Chirinko and Wilson (2008), Chirinko and Wilson (2010), Wilson (2009), Head et al. (1999), and Duranton, Gobillon and Overman (2011). Overall, the empirical evidence on the effect of tax incentives on local labor markets is still limited and more work is needed to understand how in practice these subsidies contribute to economic development.

${ }^{4}$ We follow the literature in using the term "star scientists," though it should be noted that patenters include institutions such as universities and corporations in addition to individuals. Specifically, in our biotech patent database, individuals account for $70.9 \%$ of patents, universities account for $5.6 \%$, and other institutions (mostly corporations) account for $23.5 \%$ of patents.
} 
number of star scientists in a state by 15 percent relative to states' pre-adoption baseline. This is important because of the existing evidence on the important role played by the localization of star scientists on the localization and survival of U.S. biotech clusters (Zucker, Darby, and Brewer, 1998).

Notably, most of the gains in star scientists are due to the relocation of star scientists to adopting states, with limited effect on the prolificacy of incumbent scientists already in the state. In addition, we find that the gains are concentrated among private sector inventors, both corporate and individual. We uncover little effects of subsidies on academic researchers, consistent with the fact that incentives for universities - which are mostly non-profit - are unaffected by the subsidies.

The effect of incentives on employment is not limited to top scientists, but it extends to other parts of the biotech workforce. We uncover significant effects on total employment in the Pharmaceutical and Medicine Manufacturing industry (16 percent gain); the Pharmaceutical Preparation Manufacturing industry (31 percent gain); and the scientific R\&D industry (18 percent gain). Because the effect for all workers is generally similar to the effect for stars, we infer that the incentives do not alter the ratio of stars in the workforce. ${ }^{5}$

Consistent with a model where workers are fairly mobile across states, we find limited effects on average salaries in these three industries. While we do not have a direct measure of start-up creation, we find that the number of biotech-related establishments also increases following incentive adoption. On the other hand, we find limited effects on patents following the subsidy, possibly because it takes time for biotech research to come to fruition.

We cannot rule out the possibility that the adoption of subsidies is correlated with unobserved trends in the vitality of the local economy in general or the local innovation sector in particular. However, we fail to find an effect of biotech subsidies and R\&D credits on employment in fields different from biotech. Triple difference models that include other sectors largely confirm our estimates for the employment effects.

Consistent with the presence of a local employment multiplier effect (Moretti, 2011), we do uncover an indirect effect on the local non-traded sector, including retail, construction and real estate. It appears that by increasing employment in biotech, the incentives indirectly increase

\footnotetext{
${ }^{5}$ The Pharmaceutical Preparation Manufacturing industry is an exception.
} 
employment in local services, like construction and retail, whose demand reflect the strength of the local economy.

In additional specifications, we test whether the provision of biotech-specific tax credits increases biotech employment at the expense of nearby states. We find mixed evidence of an effect on states that are geographically close, or states that are economically close as measured by worker migratory flows. If there is displacement, it is likely to be national in scope.

Finally, we provide some partial, illustrative and indirect evidence on whether there is a first mover advantage in providing incentives. In the presence of agglomeration economies and large fixed costs, the initially positive effect of the subsidy on the biotech industry of an early adopting state should be long lasting, as biotech activity keeps agglomerating in the state even after other states have matched the subsidy. On the other hand, in the absence of significant agglomeration economies and large fixed costs, the initially positive effect experienced by an early adopter will not last after competing away any relative advantage. In this case, local biotech activity will revert to the long run equilibrium level that existed before the provision of any subsidies. Empirically, we find limited evidence of a first-mover advantage for biotech incentives, although data limitations preclude us from drawing definitive conclusions.

In terms of policy implications, it is important to keep in mind that our finding that biotech subsidies are successful at attracting star scientists and at raising local biotech employment do not imply that biotech subsidies are a good use of taxpayer money. Finding that the provision of tax incentives by a state results in an increase in biotech $\mathrm{R} \& \mathrm{D}$ activity in that state does not necessarily suggests the existence of a market failure, nor does it imply that the provision of tax incentives is an efficient use of public funds. In this paper we have little to contribute to the question of local efficiency of place based policies. Efficiency of these policies from the point of view of the nation as a whole is even harder to address and is outside the scope of this paper. ${ }^{6}$

The remainder of the paper is organized as follows. In Section 2, we describe our data and the incentives available for biotech companies. In Section 3, we discuss the possible mechanisms through which incentives can affect a state economy and we present the econometric models used. The empirical results of the paper are in Section 4. Section 5 concludes.

\footnotetext{
${ }^{6}$ See Kline and Moretti (2013) for a discussion.
} 


\section{Data}

We investigate the effects of biotech and R\&D incentives on a number of different measures of economic activity in the biotech sector. The dataset used in this paper is obtained from combining several separate data sources. In this Section we describe the data sources used and we provide descriptive statistics.

Incentives. We focus our analysis on two types of state-specific incentives for innovation: R\&D tax credits and biotech-specific subsidies. The former subsidize any form of investment in $\mathrm{R} \& \mathrm{D}$, not just biotech. But given the disproportionate importance that $\mathrm{R} \& \mathrm{D}$ costs have for biotech, it is obviously an important cost shifter for firms in the industry. To quantify the magnitude of $R \& D$ tax incentives offered by states in our sample, we treat R\&D as an input into a firm's production function, whose price is the implicit rental rate, or user cost, after taxes. Extending the standard Hall-Jorgenson (1967) formula for the user cost of capital to incorporate tax and subsidies - and ignoring federal taxes just for the exposition - yields the following formula for the user cost of R\&D capital (per dollar of investment):

$$
\text { User Cost of } \mathrm{R} \& \mathrm{D}=\left(\mathrm{r}_{\mathrm{t}}+\delta\right)\left[\left(1-\mathrm{s} \mathrm{k}_{\mathrm{st}}-\mathrm{z} \mathrm{t}_{\mathrm{st}}\right) /\left(1-\mathrm{t}_{\mathrm{st}}\right)\right]
$$

where $r_{t}$ is the real interest rate in the economy, assumed to be the same for all states in any given year; $\delta$ is the economic depreciation rate of R\&D capital, assumed to be the same for all firms; $\mathrm{t}_{\mathrm{st}}$ and $\mathrm{k}_{\mathrm{st}}$ are the corporate income tax rate and the $\mathrm{R} \& \mathrm{D}$ tax credit rate in a given state and year; $s$ is the share of R\&D expenditures that qualify for the credit according to the tax code, set equal to .5 based on IRS Statistics; and $\mathrm{z}$ denotes the present discounted value of tax depreciation allowances. The formula provides a comprehensive measure of the tax advantage provided by each state in each year that is comparable across jurisdictions and periods. We use data from Wilson (2009), updated through 2010, to compute the relevant user cost of capital for each state and year in our sample.

In addition to generic $R \& D$ tax credits, states have adopted a variety of specific fiscal incentives to attract biotech activity to their jurisdiction. These incentives take various forms, including tax credits on investment or job creation, sales and use tax exemptions, low-interest 
start-up loans, and even grants. In total, 11 states have some form of incentive targeted primarily at the biotech sector. Appendix 1 provides the list of adopting states and details on each state's program. $^{7}$

One major limitation of our data is that, unlike R\&D tax credits, it is difficult to come up with a comparable measure of the generosity of the biotech incentives, due to the heterogeneity in their forms. For instance, Massachusetts adopted in 2009 a "Life Sciences Tax Incentive Program" consisting of an investment tax credit, special sales tax exemptions, and a refundable research tax credit, all applicable only for companies in life sciences. Constructing a single summary measure of the value of this program that could be compared with another state, which might have only one of these three tax incentives (though it could be especially generous) or might have another type of incentive altogether (such as low interest loans as in North Carolina or research grants as in California), is next to impossible. In principle, one could construct a proxy for the effective credit rate by taking the ratio of the total amount spent by each state for "tax expenditures" and grant outlays divided by the biotech sector revenues in the state. However, states do not typically report how much they spend on incentives separately from other items in their budget. After a comprehensive search, we were unable to find systematic data for a significant number of states. Thus, in our empirical analysis, we simply use an indicator for the adoption of biotech incentives. The coefficient on this indicator has to be interpreted as the mean effect of adoption, averaged across all adopting states.

Biotech Star Scientists. We use data on biotech patents to identify the location of prolific biotech scientists and to measure biotech innovation in a state. We purchased a proprietary data set on biotech patents from IFI Claims Patent Services, a company that provides data services associated with biotechnology and related fields. IFI's specialists, who have expertise in chemistry and biology, go through public individual patent records (from U.S. Patent and Trademark Office, USPTO) and identify all patents that involve advances in the biotechnology field. This identification is necessary because the technology classes that the USPTO assigns to patents (which change only infrequently and hence often cannot keep up with emerging technologies) do not map well to biotech, which is at the intersection of a number

\footnotetext{
${ }^{7}$ North Carolina is the earliest adopter. Because the state adopted a biotech incentive in 1984, and our data begins in 1990, North Carolina does not contribute to identification of the coefficients in our regression models.
} 
technological fields. Analyses of the biotech sector based on USPTO technology classes, as the previous literature has relied on, are likely to have difficulty cleanly identifying effects on biotech patenting given this poor mapping. To our knowledge, this paper is the first to use the IFI database or any other data specifically focused on identifying biotech patents.

The IFI's patent database contains five variables for each (IFI-identified) biotech patent from 1976 - 2010: year, inventor name, inventor city, inventor state, and USPTO patent ID number. A single patent may have multiple inventors and hence multiple observations in this data set. From these data, we construct three variables at the state-by-year level: (1) patent counts, (2) number of "star" scientists patenting in the state, and (3) number of star scientists that are new to the state in that year. The latter variable, the number of new star scientists, is the sum of an extensive margin - star scientists who were patenting in a different state in the previous year - and an intensive margin - star scientists who were in the previous year in the same state but were not "stars" (as defined below). In some specifications, we will analyze the effect of incentives on each margin separately.

For constructing patent counts by state-year, if the patent has multiple inventors from multiple states, we assign fractions of the patent to each of its inventors' states in proportion to the number of inventors of that patent in each state. For example, if a patent has four inventors, one from California, one from Oregon, and two from Washington, we would give a patent count of 0.25 to California, 0.25 to Oregon, and 0.5 to Washington. After constructing patent counts for each inventor*patent-ID observation in this way, we then simply sum biotech patent counts by state* year.

We define "star" biotech inventors, in a given year, as those that are at or above the $95^{\text {th }}$ percentile in number of biotech patents over the past ten years. In other words, stars are exceptionally prolific patenters in the biotech field. The $95^{\text {th }}$ cutoff is of course arbitrary, but our empirical results are not sensitive to it. We have also estimated our regressions based on star measures using the $90^{\text {th }}$ or $99^{\text {th }}$ percentiles and obtained similar results. Stars in a given year are 
assigned to a single state (even if they have listed different states on different patents) corresponding to the state in which they have the most patents (in that year). ${ }^{8}$

The IFI database includes inventor names and distinguishes between individual and institutional (corporations, research institutions, and universities) inventors by listing names for the latter in all uppercase. Furthermore, it is possible to separate institutions into universities and other institutions (mainly corporations) by classifying patenters with the word "university" or "college" in their name as universities. We exploit this information to measure state-year counts of patents, stars, and new stars separately for individuals, universities, and other (non-university) institutions.

Employment, Wages and Establishments. In addition to these measures of biotech innovation, we look at biotech sector employment, wages and number of establishments. While our patent data allow an exact identification of biotech patents, the same is not true for labor market and establishment data. First, NAICS does not directly and exactly identify the biotech industry including both the R\&D side and the production and sales side. Second, and more importantly, for years before 1998, SIC codes were used, and the link with biotech is even more imperfect. In practice, we consider three different NAICS industries as potentially reflecting biotech activity: Pharmaceutical and Medicine Manufacturing (NAICS 3254), Pharmaceutical Preparation Manufacturing (NAICS 325412 - a subset of 3254), Research and Development in the Physical, Engineering, and Life Sciences (NAICS 54171). ${ }^{9}$ None of these three sectors perfectly captures the biotech industry, as each of them excludes parts of biotech and includes parts of other industries that do not belong to biotech. But we hope that taken together, the three

\footnotetext{
${ }^{8}$ The city and state of the patenter may be measured with error, especially when there is a difference between the location of the inventor and the location of her employer. It is also possible that there are two or more inventors with the same name within the same city, state, and year, although such instances should be quite rare because the number of biotech patents within a city-state-year cell is rarely large and hence the probability of two inventors within that cell having the exact same name should be very small. Both of these cases would induce classical measurement error in the dependent variable, and so not a cause of bias.

${ }^{9}$ In principle, restricting the third group to R\&D in Life Science would be better, but too many states have their values set to missing to protect confidentiality. There also is a NAICS industry for "Research and Development in Biotechnology" (541711), however, employment, wage, and establishments data for this industry is only available from 2007 onward.
} 
sectors may prove informative about the industry. We also note that in our analysis, employment, salaries and number of establishments are used as dependent variables. Well-behaved measurement error in the dependent variable of linear models increases standard errors, but does not introduce any systematic bias in the estimates.

We obtain employment data by month, industry and state from the Bureau of Labor Statistics' Census of Employment and Wages (CEW) series, and aggregate to a yearly frequency. These data are based on administrative records (state Unemployment Insurance payroll reports) so they contain minimal measurement error. They cover all employers, with no minimum thresholds for employer size. We obtain data on wages and number of establishments by month and state from the Census Bureau's County Business Patterns (CBP) data series, and aggregate to a yearly frequency. Both the $\mathrm{CEW}$ and CBP data contain missing (non-disclosed) values for some state-years when disclosure of such values could potentially be used to identify specific employers. For our regressions, we construct balanced panels for each dependent variable by dropping states that do not have complete time series for that variable.

Summary Statistics. Table 1 shows summary statistics. Panel A shows the means of our variables. Columns 1 to 3 and 7 to 8 show the means in levels (which we use in the regressions) and Columns 4 to 6 show the means in per capita terms. The means are calculated over our total sample. Columns 1 and 4 report means across all states; columns 2, 3, 5, and 6 split the sample between states that adopt biotech incentives and those that do not. While adoption occurs sometimes in the middle of the sample period, the means are computed across all years in the sample. Columns 7 and 8 shows the means only for adopting states before and after the adoption.

Columns 2 and 3 indicate that states that adopt biotech incentives appear to have a stronger presence of life science industry, though much of that appears to be simply a matter of size differences: the adopters are larger states on average. Yet, even after scaling by population, the adopters tend to have a higher average level of biotech economic activity (columns 5 and 6). The most striking difference is in the number of star biotech scientists - those scientists who are major producers of biotech research. The Table indicates that adopting states have significantly 
more stars than non-adopting states. There are 7.9 star scientists per million residents in adopting states, while the corresponding figure for non-adopting states is 3.5 .

We also look at "new stars" - star scientists that are new to the state, either because they were patenting in a different state in the previous year or because they were not stars in the previous year. This group of movers and rising stars is particularly interesting, because it captures one of the stated goals of state biotech subsidies, namely to attract and grow major producers of biotech research. Just under 1 per million residents in adopting states are new stars, while new stars in non-adopting states are only 0.4 per million.

Of course, some of the differences between adopting states and non-adopting states reflect pre-existing differences among states in the penetration of the life science sector, while other differences reflect the effect of subsidies (if there is any). Absolute employment in Pharmaceutical and Medicine Manufacturing (3254), Pharmaceutical Preparation Manufacturing (325412), Research and Development in the Physical, Engineering, and Life Sciences (54171) is also higher in adopting states, although the per-capita differences are smaller. For example, $0.08 \%$ of residents in states that adopt incentives at some point during the sample period work in the Pharmaceutical and Medicine Manufacturing industry, compared with $0.07 \%$ in states that do not adopt. ${ }^{10}$ For Pharmaceutical Preparation Manufacturing, there is no discernible difference in per-capita employment.

Salaries and number of establishments also tend to be higher among adopters: the average salary in the Pharmaceutical and Medicine Manufacturing industry in states that adopt incentives is $\$ 52,710$, compared with $\$ 47,329$ in states that do not adopt (2011 dollars); the number of establishments is almost double in the former group relative to the latter.

Columns 7 and 8 of the table show the pre- and post-adoption means for adopting states. While there is more annual employment in pharmaceutical manufacturing after adoption, there are actually lower levels of stars scientists, new star scientists, R\&D employment, and patents after adoption. What this comparison of raw means is missing, and what our regression analysis will capture, is the national trends in these variables. As the regression results show, it turns out

\footnotetext{
${ }^{10}$ The states that have the most jobs per capita in the industry are Indiana (2.71\%), North Carolina $(2.13 \%)$, and Connecticut $(2.05 \%)$.
} 
that the post-adoption decline in these variables is actually smaller for adopting states compared with the pattern over time in non-adopting states.

In our empirical analysis we use the subset of states for which we have non-missing observations in at least 20 years. Columns 1 to 3 of Panel B show the number of observations, number of states, and number of years in our total sample. Columns 4 to 6 show the same for the estimation sample. The number of states in each dependent variable's balanced panel is also shown at the bottom of each column in the regression results tables. ${ }^{11}$

Lastly, to give a sense of how much of the within-state variation in the R\&D user cost is driven by variation in the $R \& D$ tax credit, we first regress the $R \& D$ user cost on state and year fixed effects and then regress the residual on the state $R \& D$ tax credit rate. The R-squared from the latter regression is 0.345 . By comparison, the $\mathrm{R}$-squared from regressing the residual on the state tax rate is just 0.004 . Because the $R \& D$ user cost is a non-linear function of these two state tax policies along with federal tax policies, interactions of the state R\&D tax credit and these other components likely explain much of the remaining variation. We conclude that the key (single) driver of within-state changes in the R\&D user cost is the R\&D credit rate.

\section{Possible Mechanisms and Econometric Models}

The adoption of subsidies for the biotech industry can affect the state economy through a number of different channels - both direct and indirect. Here we first discuss the most important channels, and then describe how we propose to empirically assess their importance.

\subsection{Mechanisms}

(A) Direct Effects: By making biotech R\&D more profitable in the state, the adoption of incentives may directly affect the state economy by increasing the size of the industry in the

\footnotetext{
${ }^{11}$ We do this because we need to have a sufficiently long time dimension in our panel to be able to identify (with reasonable precision) state fixed effects as well as the medium-run (over three years) effects of the incentives. This leads to their being a different number of states across outcomes (dependent variables) in the tables and makes the results less comparable from outcome to outcome. As a robustness check we have repeated all of the regressions with the same sample of 28 states that have non-missing data for all of the outcomes that we look at. The results are quite similar, though the standard errors are larger. (Results available on request) Limiting the sample in this way involves a considerable loss of information for most of the outcomes, many of which have data for all 50 states.
} 
state. In practice, this direct effect may result in changes in the industry's employment, wages and number of firms.

(i) Employment. To quantify the employment effect, we will begin by focusing on the effect of biotech incentives on the number of star scientists in the state. The presence of star scientists is important because they are arguably the most important input in the biotech production function.

The literature on star scientists has highlighted the role that stars have historically played in the birth and growth of the biotech industry since the mid 1970's. Star scientists have been shown to play the key role in the development of the biotech scientific discoveries and their successful commercialization. Their localization is therefore an important determinant of the localization of the biotech industry itself. Zucker, Darby and Brewer (1998) argue that the importance of these individuals, especially the more entrepreneurial among them, "derives from the tacit character of new breakthrough discoveries. In this way, knowledge, at least when it is new, is embodied in particular individuals; it cannot diffuse rapidly, as might easily-duplicated recipes."

The adoption of incentives can in principle increase the number of star scientists in a state through two channels: (a) relocation by star scientists relocate to the adopting state or (b) increase their patenting prolificacy of incumbent scientists already present in the state and their movement into the top tier of patenters. Empirically, we will seek to separate these two margins.

The effect of subsidies on biotech research is expected to be vastly different for private firms and academic institutions. Biotech incentives and R\&D tax credits typically target private sector research, not academic institutions, which are almost universally nontaxable organizations. Thus incentives should have a smaller, possibly zero, direct effect on academic researchers than on private sector researchers. While it is still possible that incentives might have an indirect feedback effect on academia through displacement (expected negative effect) or human capital spillovers and agglomeration economies (expected positive effect), this indirect effect should be smaller than the direct effect. Our empirical analysis will differentiate between biotech scientists in the private sector and in academia.

While scientists are probably the most important input in the biotech industry, they are not the only one. Quantitatively, the most important channel through which the adoption of 
incentives might affect the local economy is through increases in the overall employment in the industry. We will quantify this channel by assessing changes in overall industry employment caused by biotech incentives. Biotech incentives may help established firms to expand, or foster the creation of new biotech star-ups. While we do not have direct measures of start-up creation, we will investigate the effect of incentives on the total number of biotech firms in the state.

We note that our estimates capture the overall effect of incentives on industry employment. This overall effect is the sum of the direct effect on the size of the industry and any localized agglomeration economies, if they exist.

(ii) Wages. Of course, the adjustment to an increase in the demand for biotech workers induced by an increase in subsidies need not come entirely in the form of employment gains. If the supply of scientists or other workers in the biotech sector is not elastic, the effect of incentives on employment could be limited, but there could be an effect on salaries. Indeed, Goolsbee (1998) finds that when the federal government increases subsidies for R\&D, the immediate effect on employment is rather limited because the short run labor supply of this type of worker is quite inelastic at the national level and most of the increased spending translates into higher wages. Empirically, this appears particularly true for scientists related to defense R\&D such as physicists and aeronautical engineers.

Our setting is different in two respects. First, and most fundamentally, Goolsbee was looking at nation-wide changes, while we look at state-level policies. The elasticity of labor supply at the state level is likely to be quite different from the elasticity of labor supply at the national level. While it is difficult to add highly specialized workers in the nation as a whole in the short run, workers are mobile, and highly educated workers are particularly mobile, making state-level elasticity of labor supply likely to be significantly larger than the national level elasticity. For this reason, we expect that while wage effects may take place, at least some of the effect will manifest itself in increased employment.

Second, within each local labor market, there may be mobility across sectors. This type of mobility is rare for biotech engineers, but it is probably common for less specialized occupations, like support staff, commercial personnel, and unskilled labor, which arguably represent a significant fraction of workers in the three industries we focus on. The degree of mobility that exists between the biotech industry and the rest of the labor market does not have to 
be identical to the one that exists between government supported research sector and the rest of the labor market.

(B) Indirect Effects. In addition to the direct effect on the biotech sector, the adoption of incentives may affect parts of the state economy outside the biotech sector. First, biotech incentives need to be financed implicitly or explicitly through higher taxes on the rest of the state taxpayers. This will likely result is economically costly distortions and lower employment in other parts of the state economy. Separate from the negative effect of taxation, there might be two additional indirect effects on the local traded and non-traded sector:

(i) Employment in the Non-Traded Sector. It is possible that the employment gains in biotech indirectly may result in employment changes in the non-traded sector outside biotech through a local job multiplier effect. Every time a state economy generates a new biotech job by attracting a new biotech company, additional jobs might also be created, mainly through increased demand for local goods and services.

This multiplier effect is expected to be particularly large for innovative industries like biotech. First, workers in innovative industries tend to have higher-than-average salaries and therefore tend to support more local jobs thorough their personal consumption of local nontraded services. In addition, firms in innovative industries tend to consume more local services. Third, agglomeration economies may also be stronger in these industries, further increasing the local multiplier effect. Consistent with this hypothesis, Moretti (2011) finds that for each additional job in the manufacturing sector in a given city, 1.6 jobs are created in the local nontraded sector in the long run and that this number is significantly larger for high tech manufacturing industries and industries that are more human capital intensive.

(ii) Employment in the Traded Sector Outside Biotech In principle, it is possible that an increase in biotech activity may affect labor demand not just the local non-traded sector, but also the local traded sector. ${ }^{12}$ The sign of this relationship is a priori unknown. The increase in labor demand in the state caused by an increase in biotech activity could result in higher local wages (if local labor supply is not perfectly elastic) and therefore hurt employment in other parts of the

${ }^{12}$ This would make the placebo tests and the triple difference models discussed above invalid. 
traded sector. Unlike the case of non-tradable goods, the price of tradable goods is set on national market and cannot adjust to local economic conditions. Thus, some of the production in traded industries may be shifted to different cities. On the other hand, gains in biotech may increase the local demand for intermediate goods and services. This effect depends on the geography of the industry supply chain. While many industries are geographically clustered, the magnitude of this effect is likely to be quantitatively limited if the market for traded industries is truly national. ${ }^{13}$

In practice, however, we expect the indirect effect of biotech on the rest of the tradable sector to be limited. The biotech sector is very small with respect to the rest of all state economies. Thus, it is unlikely to generate strong general equilibrium effects on local wages. Indeed, given that we will find below that the salary effects on the biotech sector itself are small, it is unlikely that the salary effects outside biotech can be very large. ${ }^{14}$ In addition, the biotech supply chain is quite distinct from that of most other parts of the traded sector.

\subsection{Econometric Models}

We now turn to the description of our econometric models. For each of the outcome variables that we consider, we estimate a two-way fixed effects regression of the outcome on both the biotech incentive indicator variable and the R\&D user cost variable, controlling for state and year fixed effects:

$$
y_{i t}=f_{i}+f_{t}+\beta B_{i t}+\gamma r_{i t}+\varepsilon_{i t}
$$

where $y_{i t}$ is the outcome of interest; $f_{i}$ and $f_{t}$ are state and year fixed effects, respectively; $B_{i t}$ is the biotech incentive indicator, and $r_{i t}$ is the R\&D user cost. ${ }^{15}$ If incentives are successful at increasing biotech activity in a state, we expect $\beta>0$ and $\gamma<0$, since a more generous $\mathrm{R} \& \mathrm{D}$ tax credit would result in a lower user cost of R\&D investment. We do not control for total

\footnotetext{
${ }^{13}$ In addition, if agglomerations economies are important, the increase in biotech may result in more local agglomeration outside biotech.

${ }^{14}$ Moretti (2011) finds limited effect of shocks to one part of the traded sector on other parts of the traded sector.

${ }^{15}$ We jointly estimate the separate effects of the biotech incentives and the R\&D user cost rather than estimating their effects in separate regressions to avoid any possible bias due to correlation between biotech incentives and R\&D credits. Estimating the effects in separate regressions yields similar results.
} 
employment in the state, because employment in the local non-traded sector is likely to be endogenous, and vary as a function of employment in biotech (see Section 4.3).

Identification of the effect of biotech incentives and the R\&D user cost comes from variation over time within a state. We assume that while states may differ in the political influence of the local biotech industry, the exact timing of these changes is mostly driven by exogenous factors. For example, California adopted specific incentives for biotech companies when state-wide Proposition 71 in support of state funding for stem-cell research was approved by voters. While California has had a significant biotech presence since the inception of the industry in the mid-1970's, the timing of the stem-cell proposition was largely a reflection of idiosyncratic political factors, especially the imposition of constraints on the use of federal funds for stem-cell research by the G.W. Bush administration.

As far as the R\&D user cost is considered, we expect its variation to be largely exogenous as well. First, because these credits apply to all R\&D-performing industries, idiosyncratic movements in the relative size and relative political influence of the biotech sector should have a limited, if any, effect on R\&D credit adoption. Second, as with biotech incentives, the exact timing of R\&D credit adoption likely owes more to idiosyncratic political and budget conditions than to recent R\&D activity.

However, we cannot rule out that the adoption of incentives reflects unobserved differences across states in the prospects of the local biotech industry. While permanent differences across states are fully accounted for, time-varying differences are not. The sign of the potential bias is not known a priori. If the probability of adoption is correlated with unobserved factors that favor the biotech industry - as in the case where states with strengthening innovation clusters tend to adopt incentives for biotech and R\&D - then our model will over-estimate the true effect of the subsidies. On the other hand, if the probability of adoption is correlated with factors that impede growth of the biotech industry - as in the case where states that historically lack innovation clusters tend to adopt incentives for biotech or R\&D - then our models underestimate the true effect of the subsidies. 
To get a sense of the magnitude of this problem, we investigate what happens to industries other than biotech. First, we perform a series of placebo tests, where we test for whether the incentives are correlated with employment changes in high tech industries different from biotech. If states that have a growing local innovation sector are more likely to adopt incentives, we might find that biotech incentives are positively correlated with employment in the Computer industry, or the Chemical Industry. We also test for whether the incentives are correlated with changes in employment in non-high tech industries, like Food Manufacturing.

In addition, to formalize this intuition, for employment outcomes we estimate triple difference models that estimate the differential effect of incentives on the biotech industry above and beyond any effect on non-biotech industries. Specifically, we estimate the following model:

$$
y_{j i t}=f_{j i}+f_{j t}+\beta_{B I O}\left(B_{i t} \cdot B I O_{j i t}\right)+\gamma_{B I O}\left(r_{i t} \cdot B I O_{j i t}\right)+\beta_{0}\left(B_{i t}\right)+\gamma_{0}\left(r_{i t}\right)+\varepsilon_{j i t}
$$

Where the subscript $j$ indicates whether an observation is for the biotech sector or the nonbiotech sector; $f_{j i}$ and $f_{j t}$ are state*sector and year*sector fixed effects, respectively; $B I O_{j i t}$ is an indicator variable that takes the value 1 if the observation is for the biotech sector and 0 if the observation is for the non-biotech sector. Unfortunately, data limitations prevent us from extending the triple difference models to the analysis of star scientists and patents. ${ }^{16}$

Equations (1) and (2) measure short run effects. To allow for the biotech incentives or the R\&D user cost to have delayed effects, we estimate a variant of equation (1) with current plus two lags of each variable:

$$
y_{i t}=f_{i}+f_{t}+\sum_{s=0}^{2} \beta_{s} B_{i t-s}+\sum_{s=0}^{2} \gamma_{s} r_{i t-s}+\varepsilon_{i t}
$$

\footnotetext{
${ }^{16}$ Individual level patent data with the relevant geocoding information are available from the NBER Patent Database only until 2006. Given that several of the biotech incentives in our data set were adopted shortly before and after 2006, using these data to construct non-biotech measures of star scientists and patents provides too few years to estimate the effect of incentive adoption with any reasonable degree of precision.
} 
In this case we report the cumulative effects over the three years (i.e., the sum of the coefficients on the current and two lags of the biotech incentive or R\&D user cost). ${ }^{17}$ This extension is of more use for identifying the treatment effect of changes in the R\&D user cost than it is for identifying that of biotech incentives. This is because the R\&D user cost varies from year to year whereas the biotech incentive dummy variable is a step function because a change in this variable from 0 to 1 tends to be permanent. Including lags in the R\&D user cost allows for the possibility that the effect of a temporary change in the R\&D user cost may not occur for one or two years after the change. Delayed effects from the enactment of a biotech incentive will be picked up even without including lags because the value of the incentive dummy will remain 1 for years beyond the enactment. Nonetheless, it is useful to include lags of this dummy when including lags of the R\&D user cost to control for any contemporaneous correlation between adoption of the two types of subsidies. Moreover, including lags of this dummy tests for whether the effect gets larger over time by seeing whether the post-adoption outcome is even larger in periods more than one (or two) years beyond the adoption year (compared with the post-adoption outcome including the adoption year).

Residuals in our models are likely to be serially correlated. Two factors make serial correlation an especially important concern in our setting. First, the unexplained component of our outcome variables is likely to be positively serially correlated. This happens because unobserved state-specific shocks to number of biotech stars and employment in biotech are likely to be fairly persistent over time, although not completely permanent. After all, the actual number of biotech stars or employment in biotech in a state does not vary much from year to year, but it is not fixed either. Second, the key independent variables are also highly serially correlated within each state over time. The indicator for biotech subsidies takes the value of 0 in all the years before adoption and the value of 1 in all the years after adoption. The measure of R\&D user cost is also highly serially correlated. These two factors reinforce each other to create potentially large mismeasurement in the OLS standard errors (Bertrand, Duflo, Mullainathan,

\footnotetext{
${ }^{17}$ We also experimented with additional lags, which resulted in similar cumulative effects though with larger standard errors.
} 
2004). Throughout the paper, all models estimate Newey-West standard errors allowing for AR(2) serial correlation. ${ }^{18}$

To estimate the effect of a state's incentives on other states' outcomes we estimate models with spatial lags:

$$
y_{i t}=f_{i}+f_{t}+\beta B_{i t}+\gamma r_{i t}+\beta^{\text {out }} B_{i t}^{\text {out }}+\gamma^{\text {out }} r_{i t}^{\text {out }}+\varepsilon_{i t},
$$

where ${ }^{X_{i t}^{\text {out }}}$ is a spatial lag of a given variable $X=\{B, r\}$, defined as

$$
X_{i t}^{\text {out }}=\sum_{j \neq i}^{J} \omega_{i, j} X_{j, t} ; \quad \sum_{j \neq i}^{J} \omega_{i, j}=1 .
$$

A spatial lag is simply a weighted average of $X_{i t}$ from other states. The weights, $\omega_{i t}$, are the elements of a spatial weighting matrix meant to capture the relevant "relatedness" between pairs of states. We present results below based on two complementary definition of distance: (i) geographical proximity (inverse distance) between states' population centroids (provided by the Census Bureau); and (ii) economic distance as measured by population flows (from Census Bureau data on interstate migration).

Finally, we estimate models that test whether the effect of adoption of incentives depends on the order of adoption. To do this, we generate a dummy variable, $B 4_{i t}$, that is one for the first four adopters of biotech incentives and zero otherwise. (We set out to use the first three adopters, but Colorado and Missouri - both 1999 adopters - tied for third place). Similarly, we generate a dummy, $R 4_{i t}$, that is one for the first four R\&D credit adopters and zero otherwise. We then expand equation (1) above to include these dummies and their interactions with their corresponding incentive variable:

$$
y_{i t}=f_{i}+f_{t}+\beta B_{i t}+\gamma r_{i t}+\partial B 4_{i t}+\lambda R 4_{i t}+\sigma B 4_{i t} * B_{i t}+\eta R 4_{i t} * r_{i t}+\varepsilon_{i t}
$$

In the presence of strong agglomeration economies and large fixed costs, states that adopt earlier should enjoy a stronger effect $(\sigma>0$ and/or $\eta<0)$ than states that adopt later. On the

\footnotetext{
${ }^{18}$ See Bertrand, Duflo, Mullainathan (2004) for alternative solutions to this problem.
} 
other hand, in the absence of significant agglomeration economies and large fixed costs, the initially positive effect of the subsidy may decline when other states also adopt and the relative attractiveness of the state declines.

\section{Empirical Results}

\subsection{Number of Star Scientists}

We begin by estimating the effect of incentives on the most skilled part of biotech labor force, the star scientists. ${ }^{19}$ Panel A in Table 2 reports estimates of equation (1) via OLS where the dependent variable is either the number of stars (columns 1 to 3) or new stars (column 4 to 6). The two pre-adoption means provided at the bottom of the panel are the baseline number of star scientists in adopting states in the year before adoption of the biotech incentive and in the year before adoption of the adoption of R\&D subsidies, respectively. For biotech incentives, the percent effect is defined as the ratio of the coefficient over the pre-adoption mean, holding constant R\&D tax credits. For R\&D user cost, the percent effect is the effect of an increase in R\&D tax credits large enough to lower the R\&D user cost by 10 percent evaluated at the precredit-adoption sample mean, holding constant biotech incentives. ${ }^{20}$

Entries in column 1 indicate that the adoption of biotech incentives is associated with an average increase in the number of star scientist equal to 14.7. Compared with the baseline number of 100.7 star scientists on average in adopting states in the year before adoption, this effect represents a $14.6 \%$ increase. As expected, the coefficient on the R\&D user cost is negative: a higher user cost implies less R\&D investment and therefore fewer star scientists. The point estimate indicates that an increase in R\&D tax credits large enough to lower the R\&D user cost by 0.1 (about $8 \%$ of its pre-credit adoption sample mean) would raise the number of star scientists in the state by 7.8 scientists. Evaluated at the pre-credit adoption sample means for

\footnotetext{
${ }^{19}$ As noted earlier, we use the term "scientists" loosely here as about $30 \%$ of the patenters in our biotech patent database are not individuals but rather universities, corporations, and other institutions. Below, we look at the effect of incentives on stars defined separately for individual, universities, and corporations and other institutions.

${ }^{20}$ Specifically, we calculate this elasticity as $-(\partial y / \partial r) \cdot(\bar{r} / \bar{y}) / 10$ where the upper bars denote the pre-creditadoption sample means and $(\partial y / \partial r)$ is the coefficient on the R\&D user cost $(r)$.
} 
both the dependent variable and the R\&D user cost, the implied percentage increase in stars scientists from a $10 \%$ reduction in the R\&D user cost is $22.3 \%$. We regard both of these effects as economically important. ${ }^{21}$

The variable "new stars" captures positive changes over time in the number of star scientists in a state. While "stars" is a stock, "new stars" is a flow. When the number of new stars is the dependent variable, the coefficients on the incentives in the two-way fixed effects models such as equation (1) represent the effects of the incentives on the rate of change in star scientists. Estimates in columns 3 and 4 indicate that biotech incentives and reductions in the R\&D user cost are associated with an acceleration in the growth of stars scientists. Quantitatively, the effect appears strong. Entries in column 3, for example, indicate that the adoption of biotech incentives is associated with an average increase in the number of new stars of 1.9 , a $7.2 \%$ increase relative to the pre-adoption mean, though the point estimate is not statistically significant. An increase in R\&D tax credits that lowers the R\&D user cost by 10 percent would raise the number of new star scientists in the state by $17.3 \%$ relative to the baseline.

In columns 2 and 4 we report the medium run effect, as measured by the cumulative effect for the first three years. This medium run effect is statistically indistinguishable from the immediate effect. ${ }^{22}$ The percent effects of biotech incentives for stars and new stars are, respectively, $11.3 \%$ and $5.5 \%$. The percent effects of a $10 \%$ lower R\&D user cost for stars and new stars are, respectively, $24.1 \%$ and $15.3 \%$.

We are also interested in uncovering possible interaction effects of biotech subsidies and R\&D tax credits. Columns 3 and 6 show the results of including an interaction between the biotech incentive dummy and the R\&D user cost. Here, we aim to assess whether biotech and R\&D incentives have extra benefits if a state employs both of them, over and above their direct effect. We find that the interaction term is statistically different from zero, indicating that the adoption of both biotech incentives and more generous $\mathrm{R} \& \mathrm{D}$ tax credits results in an additional

\footnotetext{
${ }^{21}$ We note that comparing the magnitude of the effect of biotech subsidies to the effect of R\&D tax credits is not feasible, due to the lack of data on the generosity of biotech subsidies: We do not know whether biotech subsidies are cheap or expensive for states, compared to R\&D tax credits.

${ }^{22}$ Recall that because the R\&D user cost varies from year to year whereas the biotech incentive dummy variable is a step function, this model is more useful for R\&D user cost than it is for biotech incentives.
} 
positive effect on stars above and beyond their individual effects. (Recall that a negative coefficient on the interaction implies higher employment from having both a biotech incentive and a lower $R \& D$ user cost since the expected sign on the $R \& D$ user cost is negative. $)^{23}$

Difference-in-difference estimates in Table 2 are biased if states adopting incentives experience different trends in the number of biotech stars. In Appendix Table 2 we investigate the robustness of our estimates to the inclusion of four region-specific time trends (columns 1 and 2) and 9 division-specific time trends (columns 3 and 4). The models here are similar to the baseline models in panel A of Table 2. Estimates that condition on region or division trends are qualitatively consistent with the corresponding estimates in Table $2 .^{24}$

Intensive vs. Extensive Margin. Overall, Panel A indicates that adoption of more generous incentives by a state results in a significant increase in the number of biotech star scientists in the state. The number of star scientists in a state can change (a) because star scientists relocate to the adopting state or (b) because incumbent scientists already present in the state increase their patenting prolificacy and move into the top tier of patenters. Separating these two sources of variation is useful because it provides some information on the possible mechanism(s) underlying the incentives' effects.

In panel $\mathrm{B}$ of Table 2 we address this question by separately analyzing these extensive and intensive margins. We define the extensive margin of "new stars" in a given state in year $t$ as the flow of star patenters who were in a different state in the year $t-1$, based on year $t-1$ patent(s).

\footnotetext{
${ }^{23}$ In these models we do not report the percent effect because it is unclear how to define the pre-adoption means.

${ }^{24}$ We have performed numerous additional robustness checks that are available on request: (1) Our baseline models are based only on states for which we have non-missing observation for at least 20 consecutive years. We do this because we need to have a sufficiently long time dimension in our panel to be able to identify (with reasonable precision) state fixed effects as well as the medium-run (over three years) effects of the incentives. However, shortening the length of the panel gives qualitatively similar results, but larger standard errors. (2) In addition, we have re-estimated all of models with the same sample of 28 states that have non-missing data for all of the outcomes to increase comparability. The results are quite similar, though as one would expect the standard errors are larger. (3) We have also re-estimated our main models replacing the R\&D user cost variable with the R\&D credit rate. The results are shown in Appendix Table 3. We find that the R\&D credit rate generally has positive and significant effects on economic outcomes in the Biotech sector, consistent with the negative and significant effects of the R\&D user cost we found in our baseline specifications (given that the user cost is inversely related to the credit rate). (4) We also attempted to estimate models that include state specific trends, but standard errors were so large to make these estimates uninformative.
} 
(Patenters with patents in multiple states in a given year are assigned to the state where they have the most patents.). We define the intensive margin of "new stars" in a given state in year $t$ as the flow of star patenters who were in the same state in year $t-1$ based on year $t-1$ patent(s) and did not qualify as "stars" because their 10-year trailing biotech patent count (measured in $t-1$ ) was not in the top $5 \%$ of all biotech patenters. By construction, the sum of the intensive and extensive margins equals the variable "new star" used in Panel A.

Estimates indicate that biotech incentives are quite effective on the extensive margin, but have no discernible effect on the intensive margin, at least within 3 years from adoption. In fact, the estimated effect of biotech incentives on the extensive margin more than accounts for the total effect on new stars, with the effect on the intensive margin being negative but statistically insignificant. (The coefficient on total new stars is of course equal to the sum of the coefficients on each of the two margins.)

We find that R\&D incentives appear to stimulate both margins. The point estimate on the extensive margin is much larger, but percentage effect relative to the baseline is only slightly larger for the extensive margin. The percent effects of a $10 \%$ reduction in the R\&D user cost on the extensive and intensive margin are, respectively, $18.0 \%$ and $15.3 \%$. Overall, it seems that it is easier to incentivize existing star scientists to move to a state than it is to turn less prolific inventors already in your state into stars. We caution however, that patenting takes time. It is possible that three years are a time horizon not long enough to allow for a complete estimation of the intensive margin effect.

Private Sector Stars vs. Academic Stars. Biotech incentives and R\&D tax credits typically target private sector research, not academic institutions, which are almost universally nontaxable organizations. As argued above, the incentives should have a smaller, possibly zero, direct effect on academic researchers than on private sector researchers.

In Table 3, we separately identify the effect of subsidies on stars, depending on whether they are individual patenters, patenters working for academic institutions, or patenters working for corporations and other non-academic institutions. For both biotech incentives and R\&D tax credits, we uncover a larger percent effect on individual star patenters and corporate and other non-academic star patenters than on academic stars. In particular, the percentage effects of 
biotech incentives are $16.5 \%$ for individual stars, $7.2 \%$ for corporate and other non-academic stars, and $0.1 \%$ for academic stars. For the R\&D user cost, we find an effect for all three categories. The point estimates are larger for individual stars and corporate and non-academic stars than they are for university patenters, yet the estimate percentage effects are largest for university patenters. However, it must be noted that the percentage effects for university patenters are particularly difficult to measure given that the baseline (pre-credit-adoption) level of university new stars is very close to zero.

Overall, the results indicate that the incentives have a larger effect on individuals and corporations than they are on universities. This is consistent with the hypothesis that academic institutions may not benefit from tax incentives as much as private sector researchers.

\subsection{Overall Industry Employment}

The findings on star scientists are important not just in itself, but especially because of the role that stars play in the birth and growth of the biotech industry. But of course, the vast majority of workers in the biotech industry are not star scientists. Table 4 assess the effect of subsidies on total industry employment (measured in thousands of jobs) for the three industries that are closest to biotech: the Pharmaceutical and Medicine Manufacturing sector ( columns 1, 2 and 3); in the Pharmaceutical Preparation Manufacturing sector ( columns 4, 5, and 6), which is a subset of Pharmaceutical and Medicine Manufacturing; and in the Scientific R\&D sector ( columns 7,8 , and 9). ${ }^{25}$

Estimates indicate that adoption of biotech incentives is associated with a significant increase in the number of jobs in all three industries. The estimated employment effects are economically sizable. For example, the entry in column 1 suggests that the adoption of biotech incentives by a state is associated with 1,324 additional Pharmaceutical and Medicine Manufacturing jobs in the state. Compared with the average baseline industry employment level in adopting states in the year before adoption $(8,043)$, this amounts to a $16.5 \%$ increase in

\footnotetext{
${ }^{25}$ Note that the definition of the last industry group is not ideal, because it is rather expansive: not only it includes all life science $R \& D$, but also other types of $R \& D$ outside the life science sector. A narrower definition is not feasible. While R\&D biotech is identified in the County Business Patterns in recent years, it is not identified before 1998 .
} 
employment. The medium run effect in column 2 is slightly smaller, but not statistically different. The percentage effect is similar for employment in the R\&D industry ( columns 7 and 8). Not surprisingly, the percentage effects are largest for the Pharmaceutical Preparation Manufacturing sector - a subset of Pharmaceutical and Medicine Manufacturing and arguably a closer approximation of biotech employment - at about 30\% ( columns 4 and 5).

More generous R\&D tax credits are also associated with more employment in the three industries. An increase in $R \& D$ tax credits large enough to lower the $R \& D$ user cost by 10 percent would raise industry employment by between $6 \%$ and $18 \%$. As with biotech incentives, the percentage effects of a $10 \%$ reduction in the R\&D user cost are largest for the Pharmaceutical Preparation Manufacturing sector at $15.6 \%$. Surprisingly, the percentage employment effect of a $10 \%$ reduction in the $\mathrm{R} \& \mathrm{D}$ user cost is small and insignificant in the $\mathrm{R} \& \mathrm{D}$ industry. However, the effect becomes significant if one allows for a delayed effect by including two lags of the R\&D user cost. In this case, the cumulative effect of a $10 \%$ reduction in the user cost is $10.3 \%$.

Columns 3, 6, and 9 investigate the possible interactions of biotech subsidies and R\&D tax credits. Point estimates and percent effects suggest that having both a biotech incentive and a low R\&D user cost leads to higher employment in these sectors. This is consistent with the presence of an interaction effect uncovered above for star scientists.

The estimated effects of the subsidies for total employment in Table 4 are generally similar to the estimated effects for stars in Table 2 in percent terms. This implies that the provision of incentives does not alter the ratio of stars in the workforce. In retrospect, this is not too surprising. The share of stars is largely determined by the production function, and there is no reason to expect that the provision of subsidies alter the technology used by biotech companies. The exception seems to be the Pharmaceutical Preparation Manufacturing sector where the percent effect is significantly larger for overall employment than star scientists.

Our estimates of the effect of R\&D tax credits are consistent with some of the key estimates in the literature. Consider for example an increase in R\&D tax credits resulting in a $10 \%$ reduction in $R \& D$ user costs. Assuming that $R \& D$ costs are one-quarter of overall costs in biotech firms, a $10 \%$ reduction in R\&D user costs cause a $2.5 \%$ reduction in overall costs. Our estimates indicate that such a reduction would result in an increase in employment of $2 \%$ to $4 \%$. This range is consistent with estimates by Bartik and Erickcek (2010). In their analysis of 
Michigan's MEGA program, they find an elasticity of -0.2 of state business activity with respect to overall state and local business taxes, corresponding roughly to an elasticity of -4 with respect to a change in overall business costs, as state and local business taxes tend to be somewhere around $5 \%$ of overall business value-added.

Another study that addresses a similar question to our analysis here is Bartik and Hollenbeck (2012). They study the effects of an R\&D tax credit in the state of Washington on job creation. They find that this tax credit created jobs: employment grew by between 0.5 and 0.6 percent at the firms that claimed credits because of the tax credit. Once scaled by the size of the R\&D credit, this estimate is not inconsistent with our estimates, although somewhat smaller.

Placebos and Triple-Difference Estimates. Identification of coefficients in Table 4 comes from within-state changes over time in incentives. State fixed effects fully account for any permanent difference between states that adopt incentives and those that do not. But estimates in these difference-in-difference models may be biased if the timing of incentive adoption is correlated with unobserved shocks to a state local economy. For example, it is possible in principle that states tend to adopt biotech incentives when the local biotech sector is stronger than in the rest of the nation. This would be the case if economic strength of the local biotech industry translates into lobbying clout. If adoption is positively correlated with industry strength, our estimate of the adoption effect would be upward biased. The reverse could also be true, if states tend to adopt biotech incentives in a countercyclical/stimulate way, i.e. when the local biotech sector is weak. In this case our estimate of the adoption effect would be downward biased.

An examination of the media reporting around the time of adoption in four states did not reveal any particular pattern in the motivations used by legislators for adoption. To obtain some more systematic evidence on the validity of our identification assumption, we provide three additional pieces of information. First, as mentioned above, we include results where we condition on four region-specific trends and nine division-specific trends. Our point estimates appear robust to the inclusion of these controls (see Appendix Table 2).

Second, we test for whether the incentives are correlated with changes in employment in tradable industries other than biotech. We look only at tradable industries because increased 
activity in the biotech industry resulting from subsidies may well cause increased demand for local non-tradable services such as construction, retail, and real estate. ${ }^{26}$ Thus, for the purpose of a placebo test, we focus on other tradable industries which should not materially be affected by biotech-specific incentives, though they could be affected by more general incentives such as R\&D credits. We consider overall Manufacturing excluding Chemicals; Machinery Manufacturing; Computer and Electronic Product Manufacturing; and Food Manufacturing. Other non-chemical manufacturing industries did not have sufficient state-level data coverage.

The results are shown in Table 5. The coefficient on the biotech incentive is either insignificantly different from zero or negative in all cases, suggesting no stimulative effect from the incentive. Perhaps surprisingly, the R\&D user cost is also found to have no effect on employment in these industries. Possible reasons for this are that $R \& D$ scientists are a smaller share of total employment in these industries compared with the biotech industry and/or that labor supply of $R \& D$ workers in these industries is more inelastic.

We explore more systematically the idea of using other tradable industries as a control group by providing triple-difference estimates. Specifically, we report estimates of equation (2), using our baseline specification where outcomes now vary by state, year, and sector (where sector is "biotech" or "non-biotech") and interacting all right-hand-side variables, including year and state fixed effects, by a biotech sector indicator. The triple-difference estimates of the incentive is identified from the difference between the biotech sector and the non-biotech sector in the pre-adoption to post-adoption change in the outcome for adopting states relative to the change over the same period for non-adopting states. Unlike Table 5, here we include all nonbiotech industries in the tradable sector in the analysis, in order to use all available information on control industries. ${ }^{27}$ We do not include non-tradable industries because employment changes there are endogenous to biotech subsidies due to employment multiplier effects (see Section 4.3 below).

The results are shown in Table 6. The focus in the triple-difference models is on the coefficients on biotech incentives. The coefficients on R\&D user cost are reported for completeness but are not particularly informative on the validity of our identifying assumption:

\footnotetext{
${ }^{26}$ We investigate this possibility below.

${ }^{27}$ Data limitations preclude triple-difference estimates of the models for biotech stars in Tables 2 and 3.
} 
unlike biotech-specific incentives, R\&D tax credits affect both the treatment and the control group. The triple-difference coefficient in the table measures whether $\mathrm{R} \& \mathrm{D}$ tax credits differentially affect biotech relative to other traded industries.

We find estimates for the effects of biotech-specific incentives that are similar to those from difference in difference models. Notably, the percent effects of the biotech-specific incentives are very close to those in Table 4 . We find that reductions in the R\&D user cost increase employment in pharmaceutical manufacturing more so than in other tradable industries (as a whole), but surprisingly we find the opposite for employment in the R\&D industry.

Overall, the evidence in Tables 5 and 6 is reassuring. While we cannot rule out the possibility that that the adoption of incentives reflects unobserved time-varying differences across states in the prospects of the local biotech industry, this evidence lends some credibility to our identification assumptions.

\subsection{Employment in the Local Non-Traded Sector}

We have found that biotech-specific incentives and tax credits for R\&D result in increases in biotech employment. A related question is whether this direct effect on employment is limited to the biotech sector or it extends to other parts of the labor force through the type of multiplier effects discussed in Section 3.1 above.

Consistent with the notion of a strong local multiplier effect, Table 7 indicates that the adoption of biotech incentives results in significant employment gains in the construction industry (37,000 additional jobs, $16 \%$ of pre-adoption baseline), retail industry $(31,000$ additional jobs, $6.7 \%$ of the baseline) and real estate industry (6,000 additional jobs, $8.0 \%$ of the baseline). States adopting tax credits for R\&D experience significant employment gains in construction but not in retail or real estate. The percent effect for construction is $7.6 \%$.

These indirect effects are quantitatively very large, especially the ones for biotech incentives. Taken at face value, these effects imply significantly larger multiplier effects that the one found by Moretti (2011b) for high tech, human capital intensive industries. We note that the magnitude of these effects could in principle reflect the possibility that other policies are enacted simultaneously with the changes in biotech incentives or with changes in the generosity of $R \& D$ 
tax credits that might affect the non-traded sector. It could also reflect the presence of unobserved shocks to the local economy that are positively correlated with adoption. ${ }^{28}$

\subsection{Salaries in the Biotech Industry}

Our main focus is on employment, measured both by the number of jobs and by the number of star scientists. In additional models, we also look at salaries. Table 8 focuses on salaries. Following the standard in the literature estimating wage equations, we measure the dependent variable in log values. The coefficients on the biotech incentives thus represent elasticities; percentage effects are simply the elasticities times 100. The coefficients on the R\&D user cost represent the percent effect of a one-unit change in the R\&D user cost. We compute the percent effects of a $10 \%$ reduction in the R\&D user cost, shown in the table, by multiplying the coefficient by $10 \%$ of the mean $R \& D$ user cost in the year prior to credit adoption for adopting states. Consistent with a model where labor supply of biotech workers at the state level is fairly elastic, we find the effect of subsidies on salaries to be limited. Biotech incentives are not associated with wage increases in the Pharmaceutical and Medicine Manufacturing (columns 1 and 2) and in the Pharmaceutical Preparation Manufacturing sectors. There is a positive although small effect of adoption for the Scientific R\&D sector: adoption is associated with 0.5\% percent increase in the sector's salaries (column 5), but over a three year period the effect disappears. Turning to R\&D user costs, we find that changes in the user cost get capitalized to some extent into salaries in the pharmaceutical industries but not in the R\&D industry. However, the effect is quite small: a $10 \%$ reduction in the $R \& D$ user cost results in a $0.4 \%$ increase in the average salary in Pharmaceutical and Medicine Manufacturing as well as in the subsector of Pharmaceutical Preparation Manufacturing. In Appendix Table 2 we include of four regionspecific trends and 9 division specific trends. Our point estimates appear robust to the inclusion of these controls.

The small wage effects in Table 8 stand in contrast with Goolsbee's (1998) findings of large wage effects following labor demand increases due to policy changes. The difference is likely to be explained by the differences in the geographical scope of the analysis, as discussed in Section

\footnotetext{
${ }^{28}$ This would cast doubt on our identification strategy. However, we are not aware of any specific examples of statesponsored subsidies to the non-traded sector that tend to be systematically associated with biotech incentives.
} 
3.1 above. In our analysis policy variation occurs at the state level - thus allowing for inter-state mobility to induce significant shifts in local labor supply -while in Goolsbee's analysis the policy variation is national.

In addition, workers in the three industries under consideration are unlikely to be all specialized. A significant fraction of workers employed in biotech have skills that are not specific only to that industry. Thus, there is likely to be significant within-state, cross-sector reallocation, at least for workers in non-scientific occupations. For example, when demand for administrative staff increases in biotech in response to an increase in state subsidies, some administrative staff might leave other sectors to move to biotech. Unfortunately, we do not have salary data for scientists. In theory we would expect their salaries to be more sensitive to demand shifts than the salary of the general population, as movements across industries are less likely.

\subsection{Biotech Establishments and Biotech Patents}

One important question is whether state subsidies for innovation help the formation of start-ups. We do not have direct measures of start-up creation, but we report the effect on number of establishments. Increases in the number of establishments may arise either because state incentives foster more start up creation, or because established companies open new facilities in a state.

In Table 9 we report the effect on number of establishments. Increases in the number of establishments may arise either because state incentives foster more start up creation, or because established companies open new facilities in a state.

We find a significant effect of biotech incentives on the number of establishments in both Pharmaceutical Manufacturing and the R\&D industry. The percent effects are between 10\% and $18 \%$. By contrast, we find no significant effect of declines in the user cost of $R \& D$ on number of establishments in Pharmaceutical Manufacturing but we find a significant increase in Scientific R\&D establishments. We find that a $10 \%$ reduction in the user cost of $R \& D$ is associated with about a $14 \%$ increase in R\&D establishments, and the effect appears to grow slightly over time.

The analysis so far has focused on the inputs used by biotech firms. We now examine one measure of output: biotech patents. Given that we find an increase in employment and in star scientists - arguably important inputs in the production of innovation - one might expect a 
significant increase in number of patents filed - arguably a good proxy for output in the process of innovation. The findings, shown in Table 10, are mixed. On the one hand, we fail to find a statistically significant effect of biotech incentives on biotech patents, though the point estimate implies a fairly large percentage effect (about 14\%). On the other hand, we find a significant effect of $R \& D$ user costs, indicating that variation in $R \& D$ user costs has a more immediate effect on patent filings. The percentage effect of a $10 \%$ reduction in the $R \& D$ user cost is found to be $27.8 \%$. In Appendix Table 2 we include of four region-specific trends and 9 division specific trends. Our point estimates appear robust to the inclusion of these controls.

We also look at biotech patent counts broken out by those patented by individuals versus universities versus corporations and other non-academic institutions. The estimated percentage effects are similar across the three categories. As with total patents, the biotech incentives have no statistically significant effect while reductions in the R\&D user cost increase patents for each category by roughly $25 \%$.

\subsection{Models with Spatial Lags}

We now turn to the question of whether the provision of local incentives is a zero sum game across jurisdictions, or whether it increases aggregate biotech activity. Previous work on state tax incentives (not specific to biotech) have tended to find negative, or "beggar thy neighbor," effects of own-state incentives on other states and a zero-sum game nationally (Wilson 2009, Chirinko and Wilson 2008, and Goolsbee and Maydew 2000). We cannot directly evaluate this question, but we provide some indirect evidence by testing whether the provision of incentives results in a decline (or increase) in star scientists and employment in nearby states (see equation 4). ${ }^{29}$

We measure proximity using either a geographical definition or an economic one. In panel A of Table 11 we measure distance using a spatial weighting matrix based on population flows between states. In particular, population flows between state $i$ and state $j$ is defined as the average between the annual percent of population moving from state $\mathrm{i}$ to state $\mathrm{j}$, and the annual percent of population moving from state $\mathrm{j}$ to state $\mathrm{i}$, based on Census Bureau data. For the

\footnotetext{
${ }^{29}$ Kline and Moretti (2013) provide a model-based approach to estimating the aggregate effects of place based policies.
} 
biotech incentive, which is expected to have a positive in-state effect on star scientists, a positive coefficient on the spatial lag would imply a positive spillover of one state's incentives to star scientist employment in "nearby" states while a negative coefficient implies a negative or "beggar thy neighbor" effect. For the R\&D user cost, increases in which are expected to lower the number of star scientists, a negative coefficient implies a positive spillover while a positive coefficient implies a "beggar thy neighbor" effect.

The table indicates that for the total stock of stars, there is a significant negative effect of one state's incentives on neighboring states. The magnitude of the out-of-state effect is roughly similar to that of the own state effect, suggesting a zero-sum game nationally. However, we should note that the point estimates on the spatial lags are imprecisely estimated. Hence, we are hesitant to make definitive statements about the net effect of the incentives nationally. In contrast to this finding for the stock of star scientists, we find no evidence of spatial spillovers for entry of new stars or total employment in biotech industries. For the R\&D user cost, we find no evidence of statistically significant spatial spillovers except for the flow of new star scientist for which we find a positive spillover. ${ }^{30}$ That is, a reduction in the R\&D user cost in one state appears to increase the flow of new star scientists to both that state and its neighbors. This positive spillover could reflect regional agglomeration forming as a result of one state reducing $R \& D$ costs.

The results are quite similar if we use a spatial weighting matrix based on geographical proximity. Panel B shows estimates from model that use a distance-based weighting matrix based on the inverse of the distance between each pair of states. It includes only those states with non-missing data for the particular dependent variable in that particular regression. ${ }^{31}$

\footnotetext{
${ }^{30}$ The lack of significant negative spillovers from R\&D tax incentives on biotech stars and employment contrasts with the negative spillovers of such incentives on R\&D spending found in Wilson (2009). It is possible that spillovers are more negative outside of the biotech sector where positive agglomeration-related spillovers could be more prevalent. Another possible explanation is that $\mathrm{R} \& \mathrm{D}$ spending is much more geographically mobile than is employment. Part of the spending mobility may reflect increases in salaries of R\&D workers in tax-advantaged states. Part of it could also reflect corporations relabeling R\&D spending from one location to another in response to differentials in $R \& D$ tax incentives.

${ }^{31}$ One obvious alternative measure of distance would be an indicator for contiguity. A contiguity-based spatial weighting matrix is appealing in theory, but it is unfeasible in our setting. For employment, salaries, and establishments, there are states with missing data. This makes the contiguity weighting matrix unmeasurable for many states.
} 
The point estimates using a distance-based spatial lag are very similar to estimates in panel B, although the standard errors are higher. The two statistically significant cells in panel A are no longer significant. Overall, the findings of panel A and B points to some displacement, but are not precise enough to draw firm conclusions.

\subsection{The Effect of Early Adoption}

Finally, we test whether the effect of adopting biotech incentives is stronger for earlier adopters, as one would expect in the presence of strong agglomeration forces. To do so, we add an interaction between the biotech incentive dummy and an indicator for whether the state is one of the first four adopters of biotech incentives (see equation 5). ${ }^{32}$ Similarly, we include an interaction between the R\&D user cost and an indicator for whether the state is one of the first four adopters of an R\&D tax credit. We focus on the effects on stars, new stars, and employment in each of the three biotech-related industries.

Our estimates in Appendix Table 4 point to a generally small effect of biotech incentives for earlier adopters. For each of the five outcomes, it appears that the effect for earlier adopters is virtually zero (as the interaction effects roughly cancels out the total effects), while the effect for later adopters is stronger. For R\&D tax credits, we find that early credit adopters experienced larger pharmaceutical employment gains from the resulting drops in the R\&D user cost than did later adopters. However, for star scientists and R\&D employment, we find no significant difference in the R\&D user cost effect between early and later adopters. ${ }^{33}$

Overall, there is little evidence that early adopters enjoy larger benefits from adoption. We caution, however, that we cannot draw strong conclusions from this test, as the magnitude of the biotech incentives is unknown, and may have been set endogenously by states. In the presence of agglomeration economies, for example, late adopters face stronger incentives to overcome the early adopters' advantage, and may provide more generous subsidies.

\footnotetext{
${ }^{32} \mathrm{We}$ originally intended to use an indicator for whether the state is one of the first three adopters, but the place of third adopter is a tie between Colorado and Missouri.

${ }^{33}$ Findings are robust to the controlling for the state share of national biotech employment.
} 


\section{Conclusions}

States spend billions of dollars to attract R\&D activity to their jurisdiction. We shed light on how effective these policies are at attracting jobs in biotech. We find significant increases in the number of star scientists, the number of biotech workers and the number of establishments, but limited effects on salaries and patents. While we think that the timing of the variation in the incentive levels is largely driven by idiosyncratic political factors, we cannot rule out the possibility that it may be endogenous.

We stress that the finding that subsidies to biotech $R \& D$ raise biotech employment in a state does not tell us whether those subsidies are economically justified. Knowledge of the magnitude, the geographical scope and the direction of localized spillovers is a prerequisite for an appropriate design of an efficient innovation policy. 


\section{Bibliography}

Bartik, Timothy J. (1991). "Who Benefits from State and Local Economic Development Policies?" Kalamazoo: W.E. Upjohn Institute for Employment Research.

Bartik, Timothy J., 2002. Evaluating the impacts of local economic development policies on local economic outcomes: what has been done and what is doable? Upjohn Working Papers 03-89, W.E. Upjohn Institute for Employment Research.

Bartik, Timothy J. and George Erickcek. (2010). "The Employment and Fiscal Effects of Michigan's MEGA Tax Credit Program," Upjohn Working Papers and Journal Articles 10-164, W.E. Upjohn Institute for Employment Research.

Bartik, Timothy J. and Randal W. Eberts. (2012). "The Role of Tax Incentives and Other Business Incentives in Local Economic Development", Book chapters authored by Upjohn Institute researchers, in: Nancy Brooks \& Kieran Donaghy \& Gerrit-Jan Knaap (ed.), Oxford Handbook of Urban Economics and Planning, pages 634-654 W.E. Upjohn Institute for Employment Research.

Bartik, Timothy J., and Kevin Hollenbeck (2012). "An Analysis of the Employment Effects of the Washington High Technology Business and Occupation (B\&O) Tax Credit: Technical Report" W.E. Upjohn Institute, Upjohn Institute working paper; 12-187

Black, Dan, Natalia Kolesnikova, and Lowell Taylor, 2009. "Earnings Functions When Wages and Prices Vary by Location," Journal of Labor Economics, University of Chicago Press, vol. 27(1), pages 21-47, 01.

Bertrand, Marianne, Esther Duflo and Sendhil Mullainathan; How Much Should We Trust Differences-in-Differences Estimates?" Quarterly Journal of Economics, 2004, 119(1), pp. 249-75.

Busso, Matias, Jesse Gregory, and Patrick M. Kline. "Assessing the Incidence and Efficiency of a Prominent Place Based Policy.” NBER Working Paper 16096. National Bureau of Economic Research, June 2010.

Chirinko, Robert, and Daniel J. Wilson. "State Investment Tax Incentives: A Zero-Sum Game?" Journal of Public Economics 92(12), Dec. 2008, pp. 2362-2384.

Chirinko, Robert, and Daniel J. Wilson. (2010) "Job Creation Tax Credits: Whether, When, and Where?” FRBSF Working Paper 2010-25.

Chirinko, Robert, and Daniel J. Wilson. (2013). “Tax Competition among U.S. States: Racing to the Bottom or Riding on a Seesaw?" FRBSF Working Paper 2008-03. 
Combes, Pierre Philippe, Gilles Duranton, and Henry G. Overman, 2005. Agglomeration and the adjustment of the spatial economy. Papers in Regional Science 84 (3), 311-349.

Duranton, Gilles, Laurent Gobillon \& Henry G. Overman, 2011. "Assessing the Effects of Local Taxation using Microgeographic Data," Economic Journal, Royal Economic Society, vol. 121(555), pages 1017-1046, 09.

Duranton, Gilles, and Diego Puga, 2004. Micro-foundations of urban agglomeration economies. In: Henderson, J. Vernon, Thisse, Jacques-Francois (Eds.), Handbook of Urban and Regional Economics, vol. 4. North-Holland, Amsterdam.

Duranton, Gilles, Overman, Henry G., 2005. Testing for localization using microgeographic data. Review of Economic Studies 72 (4), 1079-1106.

Duranton Gilles. "California Dreamin': The feeble case for cluster policies" Review of Economic Statistics, 2011, 3(1), 3-45.

Duranton Gilles, Philippe Martin, Thierry Mayer, and Florian Mayneris. "The Economics of Clusters: Evidence from France," Oxford University Press, 2010.

Ellison, Glenn, and Edward L. Glaeser, 1999. The geographic concentration of industry: does natural advantage explain agglomeration? American Economic Review Papers and Proceedings 89(2), 311-316.

Faulk, Dagney. "Do State Economic Development Incentives Create Jobs? An Analysis of State Employment Tax Credits. National Tax Journal. 2002.

Government Accountability Office. 2012. "Federal Economic Development Grants to Communities with High Rates of Poverty and Unemployment." GAO-12-938R.

Glaeser, Edward L. (2001). "The economics of location-based tax incentives." Harvard Institute of Economic Research, Discussion Paper Number 1932.

Glaeser, Edward, and Joshua Gottlieb (2008). The economics of place-making policies. Brookings Papers on Economic Activity.

Goolsbee, Austan (1998). "Does Government R\&D Policy Mainly Benefit Scientists and Engineers?," American Economic Review, American Economic Association, vol. 88(2), pages 298-302, May.

Goolsbee, Austan, and Edward L. Maydew (2000). "Coveting thy neighbor's manufacturing: the dilemma of state income apportionment." Journal of Public Economics, vol. 75, pp. 125143. 
Greenstone, Michael and Enrico Moretti. (2004). "Bidding for Industrial Plants: Does Winning a 'Million Dollar Plant' Increase Welfare?" MIT Department of Economics Working Paper No. 04-39.

Greenstone, Michael, Rick Hornbeck, and Enrico Moretti. (2010). "Identifying Agglomeration Spillovers: Evidence from Million Dollar Plants", Journal of Political Economy.

Hall, Robert E. and Dale Jorgenson. (1967). "Tax Policy and Investment Behavior”, American Economic Review, 57.

Head, K., Ries, J., and Swenson, D., 1999. Attracting foreign manufacturing: investment promotion and agglomeration. Regional Science and Urban Economics 29 (2), $197-218$.

Helsley, Robert W. and William C. Strange, "Matching and Agglomeration Economics in a System of Cities," Regional Science and Urban Economics, 20,1990, pp. 189-212.

Kline, Patrick. and Enrico Moretti (2012). "Local Economic Development, Agglomeration Economies and the Big Push: 100 Years of Evidence from the Tennessee Valley Authority." 2012.

Kline, Patrick and Enrico Moretti (2013). "Place Based Policies with Unemployment”, NBER Working Paper 18758.

Marshall, Alfred (1920): Principles of Economics. London, U.K.: MacMillan and Co.

Moretti, Enrico, 2004a. Estimating the external return to higher education: evidence from crosssectional and longitudinal data. Journal of Econometrics 120 (July-August), 175-212.

Moretti, Enrico, 2004b. Workers' education, spillovers and productivity: evidence from plantlevel production functions. American Economic Review 94 (June), 656-690.

Moretti, Enrico, 2004c. Human capital externalities in cities. In: Henderson, J. Vernon, Thisse, Jacques-Francois (Eds.), Handbook of Urban and Regional Economics, vol. 4. NorthHolland, Amsterdam.

Moretti, Enrico (2011). “Local labor Markets,” Handbook of Labor Economics.

Moretti, Enrico, "Local Multipliers" American Economic Review, Papers and Proceedings (2011b).

Moretti, Enrico. “The New Geography of Jobs,” Houghton Mifflin, Boston, 2012.

Rosenthal, Stuart S., William C. Strange, 2004. Evidence on the nature and sources of agglomeration. In: Henderson, J. Vernon, Thisse, Jacques-Francois (Eds.), Handbook of Urban and Regional Economics, vol. 4. North-Holland, Amsterdam. 
Rosenthal, Stuart S., William C. Strange, 2003. Geography, industrial organization, and agglomeration. Review of Economics and Statistics 85 (2), 377-393.

Rosenthal, Stuart S., William C. Strange, 2008. The attenuation of human capital spillovers. Journal of Urban Economics 64 (2), 373-389.

Story, Louise 2013 “As Companies Seek Tax Deals, Governments Pay High Price”, New York Times, Dec 1, 2013.

Wilson, Daniel J. (2009). "Beggar Thy Neighbor? The In-State, Out-of-State, and Aggregate Effects of R\&D Tax Credits.” Review of Economics and Statistics 91(2), 431-436.

Zucker, Lynne G, Michael R. Darby, and Marilynn B. Brewer, 1998. "Intellectual Human Capital and the Birth of U.S. Biotechnology Enterprises," American Economic Review, American Economic Association, vol. 88(1), pages 290-306, March. 
Table 1. Summary Statistics

Panel A. Means

Mean (in levels)

Mean (per 100,000 residents)

Mean (in levels) -- Adopting States Only

\begin{tabular}{|c|c|c|c|c|c|c|c|c|}
\hline \multirow[b]{2}{*}{ Variable Name } & \multicolumn{3}{|c|}{ Mean (in levels) } & \multicolumn{3}{|c|}{ Mean (per 100,000 residents) } & \multicolumn{2}{|c|}{ Mean (in levels) -- Adopting States Only } \\
\hline & All States & $\begin{array}{c}\text { Biotech } \\
\text { Incentive } \\
\text { Adopters }\end{array}$ & $\begin{array}{c}\text { Non- } \\
\text { adopters }\end{array}$ & All States & $\begin{array}{l}\text { Biotech } \\
\text { Incentive } \\
\text { Adopters }\end{array}$ & Non-adopters & Pre-adoption mean & Post-adoption mean \\
\hline Star Scientists & 28.04 & 80.19 & 15.32 & 0.436 & 0.790 & 0.349 & 90.78 & 63.30 \\
\hline New Star Scientists & 9.17 & 24.37 & 5.46 & 0.053 & 0.096 & 0.043 & 26.37 & 18.13 \\
\hline Employment in Pharmaceutical and Medicine Manuf. & 5,529 & 8,058 & 4,853 & 74.145 & 83.348 & 71.687 & 7,211 & 9,257 \\
\hline Employment in Pharmaceutical Preparation Manufact. & 4,563 & 5,958 & 4,191 & 52.809 & 52.136 & 52.990 & 4,742 & 7,920 \\
\hline Employment in Scientific R\&D & 9,026 & 18,465 & 6,655 & 175.131 & 199.365 & 169.043 & 20,115 & 16,132 \\
\hline Salaries in Pharmaceutical and Medicine Manuf. & 48,656 & 52,710 & 47,329 & -- & -- & -- & 50,264 & 56,904 \\
\hline Salaries in Pharmaceutical Preparation Manufact. & 50,294 & 51,960 & 49,631 & -- & -- & -- & 51,494 & 52,742 \\
\hline Salaries in Scientific R\&D & 46,420 & 51,869 & 44,943 & -- & -- & -- & 42,574 & 67,360 \\
\hline Establishments in Pharmaceutical and Medicine Manuf. & 35.20 & 67.01 & 27.02 & 0.599 & 0.781 & 0.552 & 70.55 & 61.46 \\
\hline Establishments in Pharmaceutical Preparation Manufact. & 17.89 & 29.84 & 14.72 & 0.298 & 0.319 & 0.292 & 30.56 & 28.72 \\
\hline Establishments in Scientific R\&D & 226.81 & 513.70 & 156.84 & 4.465 & 5.336 & 4.252 & 546.68 & 462.12 \\
\hline Number of Patents & 78.33 & 211.78 & 45.78 & 1.288 & 2.090 & 1.093 & 239.12 & 169.62 \\
\hline Biotech Incentive Dummy & 0.081 & 0.414 & 0 & 0.002 & 0.011 & 0.000 & 0.000 & 1.000 \\
\hline R\&D User Cost & 1.175 & 1.171 & 1.176 & 0.059 & 0.027 & 0.066 & 1.171 & 1.171 \\
\hline
\end{tabular}

Panel B. Observation Counts

Regression Sample

\begin{tabular}{|c|c|c|c|c|c|c|}
\hline \multirow{2}{*}{ Variable Name } & \multirow{2}{*}{\multicolumn{3}{|c|}{ \#\# of states* }} & \\
\hline & & & & $\mathrm{N}$ & \# of states & \# of years \\
\hline Star Scientists & 1071 & 51 & 21 & 1071 & 51 & 21 \\
\hline New Star Scientists & 1071 & 51 & 21 & 1071 & 51 & 21 \\
\hline Employment in Pharmaceutical and Medicine Manuf. & 996 & 47 & 21 & 798 & 38 & 21 \\
\hline Employment in Pharmaceutical Preparation Manufact. & 929 & 44 & 21 & 588 & 28 & 21 \\
\hline Employment in Scientific R\&D & 1046 & 49 & 21 & 987 & 47 & 21 \\
\hline Salaries in Pharmaceutical and Medicine Manuf. & 693 & 47 & 20 & 618 & 43 & 18 \\
\hline Salaries in Pharmaceutical Preparation Manufact. & 499 & 28 & 20 & 438 & 37 & 18 \\
\hline Salaries in Scientific R\&D & 900 & 45 & 20 & 670 & 40 & 18 \\
\hline Establishments in Pharmaceutical and Medicine Manuf. & 1020 & 51 & 20 & 1020 & 51 & 20 \\
\hline Establishments in Pharmaceutical Preparation Manufact. & 1000 & 50 & 20 & 1000 & 50 & 20 \\
\hline Establishments in Scientific R\&D & 1020 & 51 & 20 & 1020 & 51 & 20 \\
\hline Number of Patents & 1071 & 51 & 21 & 1071 & 51 & 21 \\
\hline Biotech Incentive Dummy & 1071 & 51 & 21 & 1071 & 51 & 21 \\
\hline R\&D User Cost & 1071 & 51 & 21 & 1071 & 51 & 21 \\
\hline
\end{tabular}

* With at least one non-missing observation 
Table 2. The Effect of Incentives on the Number of Star Scientists

\begin{tabular}{|c|c|c|c|c|c|c|}
\hline & 1 & 2 & 3 & 4 & 5 & 6 \\
\hline Panel A. Stars \& New Stars & \multicolumn{3}{|c|}{ Stars } & \multicolumn{3}{|c|}{ New Stars } \\
\hline \multicolumn{7}{|l|}{ A1 Contemporaneous Effects } \\
\hline \multirow[t]{2}{*}{ Biotech Incentive } & $14.680 *$ & & $632.270 *$ & 1.905 & & 104.468 \\
\hline & $(8.527)$ & & $(356.313)$ & $(1.987)$ & & $(81.742)$ \\
\hline R\&D User Cost & $\begin{array}{l}-77.786 * * \\
(28.908)\end{array}$ & & $\begin{array}{l}-62.186 * * \\
(25.595)\end{array}$ & $\begin{array}{l}-18.402 * * \\
(7.864)\end{array}$ & & $\begin{array}{l}-15.812 * * \\
(7.403)\end{array}$ \\
\hline Biotech Incentive * R\&D User Cost & & & $\begin{array}{l}-531.288 * \\
(301.021)\end{array}$ & & & $\begin{array}{r}-88.230 \\
(68.852)\end{array}$ \\
\hline \multicolumn{7}{|l|}{ A2 Cumulative Effects ( $0-2$ years) } \\
\hline Biotech Incentive & \multicolumn{3}{|c|}{11.421} & \multicolumn{3}{|c|}{1.451} \\
\hline \multirow[t]{2}{*}{ R\&D User Cost } & \multirow{2}{*}{\multicolumn{3}{|c|}{$\begin{array}{l}-84.113 * * \\
(33.011)\end{array}$}} & \multicolumn{3}{|c|}{$-16.290 *$} \\
\hline & & & & \multicolumn{3}{|c|}{$(8.583)$} \\
\hline Pre-Biotech-Incentive-Adoption Mean & & \multirow{2}{*}{\multicolumn{3}{|c|}{$\begin{array}{l}26.556 \\
12.248\end{array}$}} \\
\hline Pre-Credit-Adoption Mean & \multicolumn{3}{|c|}{40.158} & & & \\
\hline Percent Effect of Biotech Incentives & \multicolumn{3}{|c|}{11.345} & \multicolumn{3}{|c|}{$\begin{array}{l}12.248 \\
5.466\end{array}$} \\
\hline Percent Effect of R\&D User Cost & 22.303 & \multicolumn{2}{|l|}{24.118} & \multicolumn{3}{|c|}{$17.300 \quad 15.314$} \\
\hline Panel B. New Stars & & tars, Extensive I & & & tars, Intensive & \\
\hline \multicolumn{7}{|l|}{ B1 Contemporaneous Effects } \\
\hline Biotech Incentive & $\begin{array}{c}3.037 \text { * } \\
(1.758)\end{array}$ & & $\begin{array}{l}\mathbf{1 4 1 . 8 2 6} * * \\
(70.035)\end{array}$ & $\begin{array}{c}-1.132 \\
(.847)\end{array}$ & & $\begin{array}{r}-37.358 \\
(36.058)\end{array}$ \\
\hline R\&D User Cost & $\begin{array}{l}-14.027 \text { ** } \\
(6.474)\end{array}$ & & $\begin{array}{c}-10.522 * \\
(6.053)\end{array}$ & $\begin{array}{l}-4.375 * \\
(2.531)\end{array}$ & & $\begin{array}{l}-5.290 * * \\
(2.475)\end{array}$ \\
\hline Biotech Incentive * R\&D User Cost & & & $\begin{array}{c}-119.394 * * \\
(59.183)\end{array}$ & & & $\begin{array}{r}31.164 \\
(30.418)\end{array}$ \\
\hline \multicolumn{7}{|l|}{ B2 Cumulative Effects ( $0-2$ years) } \\
\hline Biotech Incentive & \multicolumn{3}{|c|}{2.674} & \multicolumn{3}{|c|}{-1.223} \\
\hline R\&D User Cost & & $\begin{array}{l}-13.455 * \\
(7.097)\end{array}$ & & & $\begin{array}{r}-2.835 \\
(3.259)\end{array}$ & \\
\hline Pre-Biotech-Incentive-Adoption Mean & & 20.778 & & & 5.778 & \\
\hline Pre-Credit-Adoption Mean & & 8.959 & & & 3.289 & \\
\hline Percent Effect of Biotech Incentives & 14.617 & 12.870 & & -19.585 & -21.161 & \\
\hline Percent Effect of R\&D User cost & 18.029 & 17.294 & & 15.315 & 9.924 & \\
\hline Sample Period & $1990-2010$ & $1992-2011$ & $1990-2010$ & $1990-2010$ & $1992-2010$ & $1990-2010$ \\
\hline Number of Observations & 1071 & 969 & 1071 & 1071 & 969 & 1071 \\
\hline $\begin{array}{l}\text { Notes. Regressions estimated via OLS. } \\
\text { numbers of star scientist in adopting sta } \\
\text { coefficient over the pre-adoption mean } \\
\text { R\&D user cost by } 10 \text { percent (relative to } \\
\text { the extensive margin of "new stars" in a } \\
\text { Patenters with patents in multiple state } \\
\text { state in year } t \text { as the flow of star paten } \\
\text { trailing biotech patent count measured } \\
\text { and year fixed effects. }\end{array}$ & $\begin{array}{l}\text { errors based on } \\
\text { year before ad } \\
\text { constant } R \& D \text { ta } \\
\text { ge among adopt } \\
\text { te in year } t \text { as th } \\
-1 \text { are assigned } \\
\text { were in the sam } \\
\text { not in the top }\end{array}$ & $\begin{array}{l}y \text {-West VC estir } \\
\text { hof incentive or } \\
\text { dits. For R\&D us } \\
\text { ates), holding c } \\
\text { Nof star patent } \\
\text { ingle state base } \\
\text { in year t- } 1 \text { bas } \\
\text { all biotech pate }\end{array}$ & $\begin{array}{l}\text { with within-stat } \\
\text { t. For biotech inc } \\
\text { t, is the effect of } \\
\text { t biotech incent } \\
\text { to were in a diffe } \\
\text { heir modal state } \\
\text { year's } \mathrm{t}-1 \text { paten } \\
\text { Sample include }\end{array}$ & $\begin{array}{l}\text { (2) errors. Pre-a } \\
\text { ves, the percen } \\
\text { ncrease in R\&D } \\
\text { Panel A incluc } \\
\text { state in the ye } \\
\text { define the inte } \\
\text { and did not qual } \\
\text { ta for } 51 \text { states. }\end{array}$ & $\begin{array}{l}\text { tion means ar } \\
\text { ect is defined } \\
\text { credits large e } \\
\text { ll patenters. I } \\
1 \text {, based on y } \\
\text { e margin of " } \\
\text { is "stars" beca } \\
\text { models includ }\end{array}$ & $\begin{array}{l}\text { oaseline } \\
\text { ratio of the } \\
\text { to lower the } \\
\text { el B, we define } \\
1 \text { patent(s). } \\
\text { ars" in a given } \\
\text { eir 10-year } \\
\text { fixed effects }\end{array}$ \\
\hline
\end{tabular}




\begin{tabular}{|c|c|c|c|c|c|c|}
\hline & \multicolumn{3}{|c|}{ Stars } & \multicolumn{3}{|c|}{ New Stars } \\
\hline & (1) & $(2)$ & (3) & (4) & (5) & (6) \\
\hline \multicolumn{7}{|l|}{ Panel A. Individual } \\
\hline \multicolumn{7}{|l|}{ A1 Contemporaneous Effects } \\
\hline \multirow[t]{2}{*}{ Biotech Incentive } & $13.171 *$ & & $565.095 *$ & 2.249 & & 119.119 \\
\hline & $(7.325)$ & & $(305.030)$ & $(1.888)$ & & $(77.656)$ \\
\hline \multirow[t]{2}{*}{ R\&D User Cost } & $-61.609 * *$ & & $-47.669 * *$ & $-15.982 * *$ & & $-13.030 *$ \\
\hline & $(23.957)$ & & $(20.883)$ & $(7.345)$ & & $(6.825)$ \\
\hline \multirow[t]{2}{*}{ Biotech Incentive * R\&D User Cost } & & & $-474.798 *$ & & & -100.539 \\
\hline & & & $(257.737)$ & & & $(65.490)$ \\
\hline \multicolumn{7}{|l|}{ A2. Cumulative Effects ( $0-2$ years) } \\
\hline \multirow[t]{2}{*}{ Biotech Incentive } & & 10.806 & & & 1.830 & \\
\hline & & $(6.974)$ & & & $(1.826)$ & \\
\hline \multirow[t]{2}{*}{ R\&D User Cost } & & $-66.265 * *$ & & & $-14.642 *$ & \\
\hline & & $(27.325)$ & & & (8.159) & \\
\hline Pre-Biotech-Incentive-Adoption Mean & & 79.778 & & & 24.556 & \\
\hline Pre-Credit-Adoption Mean & & 31.930 & & & 11.506 & \\
\hline Percent Effect of Biotech Incentives & 16.509 & 13.545 & & 9.161 & 7.454 & \\
\hline Percent Effect of R\&D User Cost & 22.217 & 23.896 & & 15.994 & 14.653 & \\
\hline \multicolumn{7}{|l|}{ Panel B. Corporate } \\
\hline \multicolumn{7}{|l|}{ B1 Contemporaneous Effects } \\
\hline \multirow[t]{2}{*}{ Biotech Incentive } & 1.263 & & 62.425 & -0.434 & & -14.668 \\
\hline & $(1.309)$ & & $(56.429)$ & $(.293)$ & & $(11.781)$ \\
\hline \multirow[t]{2}{*}{ R\&D User Cost } & $-14.800 * * *$ & & $-13.255 * * *$ & $-2.137 * *$ & & $-2.497 * * *$ \\
\hline & $(4.770)$ & & $(4.422)$ & $(.975)$ & & $(.968)$ \\
\hline \multirow[t]{2}{*}{ Biotech Incentive * R\&D User Cost } & & & -52.615 & & & 12.245 \\
\hline & & & $(47.642)$ & & & (9.957) \\
\hline \multicolumn{7}{|l|}{ B2 Cumulative Effects ( $0-2$ years) } \\
\hline \multirow[t]{2}{*}{ Biotech Incentive } & & 0.431 & & & -0.441 & \\
\hline & & $(1.238)$ & & & $(.322)$ & \\
\hline \multirow[t]{2}{*}{ R\&D User Cost } & & $-16.334 * * *$ & & & -1.500 & \\
\hline & & $(5.524)$ & & & (1.030) & \\
\hline Pre-Biotech-Incentive-Adoption Mean & & 17.667 & & & 2.000 & \\
\hline Pre-Credit-Adoption Mean & & 7.316 & & & 1.064 & \\
\hline Percent Effect of Biotech Incentives & 7.150 & 2.438 & 353.347 & -21.676 & -22.068 & -733.379 \\
\hline Percent Effect of R\&D User Cost & 23.293 & 25.709 & 20.862 & 23.131 & 16.237 & 27.023 \\
\hline Panel C. University & & & & & & \\
\hline C1 Contemporaneous Effects & & & & & & \\
\hline Biotech Incentive & 0.004 & & 0.644 & -0.029 & & -1.750 \\
\hline & $(.191)$ & & $(6.226)$ & $(.057)$ & & $(1.746)$ \\
\hline R\&D User Cost & $-2.027 *$ & & $-2.011 *$ & $-0.624 *$ & & $-0.667 *$ \\
\hline & $(1.221)$ & & $(1.213)$ & $(.368)$ & & $(.368)$ \\
\hline Biotech Incentive * R\&D User Cost & & & -0.550 & & & 1.481 \\
\hline & & & $(5.299)$ & & & $(1.494)$ \\
\hline C2 Cumulative Effects ( $0-2$ years) & & & & & & \\
\hline Biotech Incentive & & -0.083 & & & -0.054 & \\
\hline & & $(.200)$ & & & $(.063)$ & \\
\hline R\&D User Cost & & $-2.277 *$ & & & $-0.819 * *$ & \\
\hline & & $(1.340)$ & & & $(.412)$ & \\
\hline Pre-Biotech-Incentive-Adoption Mean & & 3.333 & & & 0.222 & \\
\hline Pre-Credit-Adoption Mean & & 2.056 & & & 0.120 & \\
\hline Percent Effect of Biotech Incentives & 0.119 & -2.502 & & -13.121 & -24.386 & \\
\hline Percent Effect of R\&D User Cost & 11.352 & 12.747 & & 59.720 & 78.404 & \\
\hline Sample Period & $1990-2010$ & $1992-2010$ & $1990-2010$ & $1990-2010$ & $1992-2010$ & $1990-2010$ \\
\hline Number of Observations & 1071 & 969 & 1071 & 1071 & 969 & 1071 \\
\hline
\end{tabular}

Notes: Regressions estimated via OLS. Standard errors based on Newey-West VC estimator with within-state AR(2) errors. Pre-adoption means are the baseline numbers of star scientist in adopting states in the year before adoption of incentive or credit. For biotech incentives, the percent effect is defined as the ratio of the coefficient over the pre-adoption mean, holding constant R\&D tax credits. For R\&D user cost, is the effect of an increase in R\&D tax credits large enough to lower the R\&D user cost by 10 percent (relative to its average among adopting states), holding constant biotech incentives. Panel A includes individual patenters. Panel includes corporae patenters. Panel C includes aacdemic patenters. Sample includes data for 51 states. All models include state fixed effects and year fixed effects. 
Table 4. The Effect of Incentives on Employment in Biotech Related Industries

\begin{tabular}{|c|c|c|c|c|c|c|c|c|c|}
\hline \multirow[b]{3}{*}{ Contemporaneous Effects } & \multicolumn{3}{|c|}{ Pharmaceutical and Medicine Manufacturing (3254) } & \multicolumn{3}{|c|}{ Pharmaceutical Preparation Manufacturing (325412) } & \multicolumn{3}{|c|}{$\begin{array}{l}\text { Research \& Development in the Physical, } \\
\text { Engineering, and Life Sciences (54171) }\end{array}$} \\
\hline & $(1)$ & $(2)$ & (3) & (4) & $(5)$ & (6) & (7) & (8) & (9) \\
\hline & & & & & & & & & \\
\hline Biotech Incentive & $\begin{array}{l}1.324 * * \\
(.658)\end{array}$ & & $\begin{array}{l}64.682 * * \\
(29.513)\end{array}$ & $\begin{array}{l}1.796 * * \\
(.740)\end{array}$ & & $\begin{array}{c}47.858 * \\
(27.334)\end{array}$ & $\begin{array}{l}3.951 * * * \\
(1.482)\end{array}$ & & $\begin{array}{l}157.398 \\
(59.433)\end{array}$ \\
\hline R\&D User Cost & $\begin{array}{l}-8.355 * * \\
(3.476)\end{array}$ & & $\begin{array}{l}-6.115 * \\
(3.167)\end{array}$ & $\begin{array}{l}-8.793 * * \\
(4.402)\end{array}$ & & $\begin{array}{r}-6.327 \\
(3.943)\end{array}$ & $\begin{array}{l}-5.844 \\
(4.150)\end{array}$ & & $\begin{array}{r}-1.801 \\
(3.579)\end{array}$ \\
\hline Biotech Incentive * R\&D User Cost & & & $\begin{array}{l}-54.761 * * \\
(25.317)\end{array}$ & & & $\begin{array}{l}-39.848 * \\
(23.416)\end{array}$ & & & $\begin{array}{r}-132.002 \\
(50.520)\end{array}$ \\
\hline \multicolumn{10}{|l|}{ Cumulative Effects (0-2 years) } \\
\hline Biotech Incentive & & $\begin{array}{l}1.190 * \\
(.700)\end{array}$ & & & $\begin{array}{l}1.741 \text { ** } \\
(.784)\end{array}$ & & & $\begin{array}{l}4.037 * * \\
(1.980)\end{array}$ & \\
\hline R\&D User Cost & & $\begin{array}{l}-10.030 * * \\
(3.953)\end{array}$ & & & $\begin{array}{l}-9.819 * \\
(5.329)\end{array}$ & & & $\begin{array}{l}-9.517 * \\
(5.593)\end{array}$ & \\
\hline \multicolumn{10}{|l|}{ Pre-Biotech-Incentive-Adoption } \\
\hline Mean & & 8.043 & & & 5.792 & & & 21.701 & \\
\hline Pre-Credit-Adoption Mean & & 7.698 & & & 6.495 & & & 10.611 & \\
\hline Percent Effect of Biotech Incentive & 16.456 & 14.791 & & 31.016 & 30.062 & & 18.206 & 18.601 & \\
\hline Percent Effect of R\&D User Cost & 12.496 & 15.003 & & 15.589 & 17.409 & & 6.341 & 10.327 & \\
\hline Sample Period & 1990-2009 & 1990-2009 & 1990-2009 & $1990-2009$ & 1990-2009 & 1990-2009 & $1990-2009$ & $1990-2009$ & $1990-2009$ \\
\hline Number of States & 38 & 38 & 38 & 28 & 28 & 28 & 47 & 47 & 47 \\
\hline Number of Observations & 798 & 722 & 798 & 588 & 532 & 588 & 987 & 893 & 987 \\
\hline
\end{tabular}

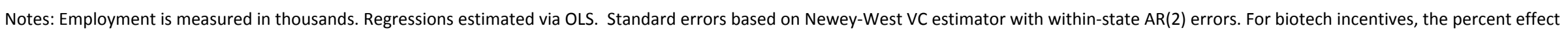

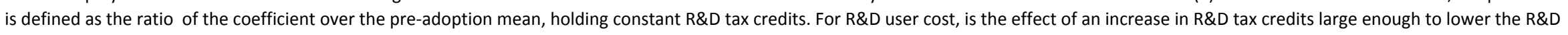
user cost by 10 percent (relative to its average among adopting states), holding constant biotech incentives. All models include state fixed effects and year fixed effects. 
Table 5. The Effect of Biotech Incentives on Employment in Other Industries in the Traded Sector

\begin{tabular}{|c|c|c|c|c|c|c|c|c|}
\hline \multirow[b]{3}{*}{ Contemporaneous Effects } & \multicolumn{2}{|c|}{ Chemical } & \multicolumn{2}{|c|}{ Machinery Manufacturing } & \multicolumn{2}{|c|}{ Computer and Electronic Products } & \multicolumn{2}{|c|}{ Food Manufacturing } \\
\hline & (1) & (2) & (3) & $(4)$ & $(5)$ & (6) & $(7)$ & (8) \\
\hline & & & & & & & & \\
\hline \multirow[t]{2}{*}{ Biotech Incentive } & -22.240 & & -0.098 & & $-12.825 *$ & & -2.158 & \\
\hline & $(18.917)$ & & $(1.273)$ & & $(5.386)$ & & $(.748)$ & \\
\hline \multirow[t]{2}{*}{ R\&D User Cost } & 56.965 & & -1.383 & & 22.497 & & 4.376 & \\
\hline & (83.436) & & (9.663) & & $(15.182)$ & & $(4.085)$ & \\
\hline \multicolumn{9}{|l|}{ Cumulative Effects ( $0-2$ years) } \\
\hline \multirow[t]{2}{*}{ Biotech Incentive } & & -17.571 & & 0.487 & & $-12.836 * *$ & & $-2.410 * * *$ \\
\hline & & $(22.833)$ & & $(1.556)$ & & $(6.291)$ & & $(.659)$ \\
\hline \multirow[t]{2}{*}{ R\&D User Cost } & & 31.212 & & -1.097 & & 23.770 & & 3.167 \\
\hline & & $(101.754)$ & & $(11.653)$ & & $(18.456)$ & & $(4.508)$ \\
\hline Pre-Biotech-Incentive-Adoption Mean & \multicolumn{2}{|c|}{368.308} & \multirow{2}{*}{\multicolumn{2}{|c|}{23.735}} & 63.676 & & \multicolumn{2}{|c|}{42.436} \\
\hline Pre-Credit-Adoption Mean & \multicolumn{2}{|c|}{322.756} & 29.093 & & 40.551 & & \multicolumn{2}{|c|}{34.513} \\
\hline Percent Effect of Biotech Incentives & -6.038 & -4.771 & -0.415 & 2.053 & -20.141 & -20.158 & -5.084 & -5.679 \\
\hline Percent Effect of R\&D User Cost & -2.032 & -1.113 & 0.547 & 0.434 & -6.388 & -6.749 & -1.460 & -1.057 \\
\hline Sample Period & $1990-2009$ & 1990-2009 & $1990-2009$ & $1990-2009$ & 1990-2009 & $1990-2009$ & $1990-2009$ & 1990-2009 \\
\hline Number of States & 48 & 48 & 49 & 49 & 49 & 49 & 51 & 51 \\
\hline Number of Observations & 1008 & 912 & 1029 & 931 & 1029 & 931 & 1071 & 969 \\
\hline
\end{tabular}

Notes. Regressions estimated via OLS. Standard errors based on Newey-West VC estimator with within-state AR(2) errors. Employment is measured in thousands. For biotech incentives, the percent effect is defined as the ratio of the coefficient over the pre-adoption mean, holding constant R\&D tax credits. For R\&D user cost, is the effect of an increase in R\&D tax credits large enough to lower the R\&D user cost by 10 percent (relative to its average among adopting states), holding constant biotech incentives. Sample includes data for 51 states. All models include state fixed effects and year fixed effects. 
Table 6. Triple Difference Estimates

Employment (3254)

(1)
Employment (325412)

(2)
Employment (54171)

(3)

Contemporaneous Effects

Biotech Incentive - Biotech Industry

R\&D User Cost - Biotech Industry

Pre-Biotech-Incentive-Adoption Mean

Pre-Credit-Adoption Mean

Percent Effect of Biotech Incentives

Percent Effect of R\&D User Cost

Sample Period

Number of Observations

$1.290 * *$
$(.658)$
$-1.165 * * *$
$(.324)$
8.043
7.698
16.042
1.742
$1990-2009$
1595

$1.801 * *$
$(.741)$
$-8.996 * *$
$(4.406)$
5.792
6.495
31.098
15.950
$1990-2009$
1176

3.862

(1.470)

$4.447 * * *$

(.837)

21.701

10.611

17.795

$-4.826$

1990-2009

1973

Notes: Regressions estimated via OLS. Standard errors based on Newey-West VC estimator with within-state AR(2) errors. Pre-adoption means are the baseline numbers of star scientists in adopting states in the year before adoption of incentive or credit. For biotech incentives, the percent effect is defined as the ratio of the coefficient over the pre-adoption mean, holding constant R\&D tax credits. Sample includes data for 51 states. All models include indicators for state, year, biotech sector, as well as the the interaction of state and biotech, and year and biotech. 
Contemporaneous Effects

Biotech Incentive

R\&D User Cost

Cumulative Effects (0-2 years)

Biotech Incentive

R\&D User Cost

Pre-Biotech-Incentive-Adoption Mean

Pre-Credit-Adoption Mean

Percent Effect of Biotech Incentives

Percent Effect of R\&D User Cost

Sample Period

Number of States

Number of Observations

\begin{tabular}{|c|c|c|c|c|}
\hline \multicolumn{2}{|c|}{ Constr } & \multicolumn{2}{|c|}{ Retail } & \multirow[b]{2}{*}{ (5) } \\
\hline (1) & (2) & (3) & (4) & \\
\hline $36.819 * *$ & & $31.349 *$ & & $5.814 * * *$ \\
\hline$(14.623)$ & & (10.867) & & $(2.034)$ \\
\hline$-87.570 *$ & & -18.286 & & -5.021 \\
\hline (49.198) & & (40.324) & & (6.680) \\
\hline
\end{tabular}

$32.185 * * *$

(11.447)

$-43.734$

(46.676)

470.79

229.83

131.86

16.02

7.647

1990-2009

50

1050
(57.853)

15.28

11.623

1990-2009
950

\begin{tabular}{rr}
\multicolumn{3}{c}{470.79} \\
6.66 & 312.45 \\
0.674 & 6.84 \\
$1990-2009$ & 1.612 \\
51 & $590-2009$ \\
1071 & 569
\end{tabular}

$6.098 * * *$

(2.324)

$-10.560$

(7.712)

73.12

40.68

$\begin{array}{ll}7.95 & 8.34\end{array}$

$1.421 \quad 2.989$

1990-2009 1990-2009

$51 \quad 51$

$1071 \quad 969$

Notes. Regressions estimated via OLS. Standard errors based on Newey-West VC estimator with within-state AR(2) errors. Employment is measured in thousands. For biotech incentives, the percent effect is defined as the ratio of the coefficient over the pre-adoption mean, holding constant R\&D tax credits. For R\&D user cost, is the effect of an increase in R\&D tax credits large enough to lower the R\&D user cost by 10 percent (relative to its average among adopting states), holding constant biotech incentives. All models include state fixed effects and year fixed effects. 
Table 8. The Effect of Incentives on Salaries

\begin{tabular}{|c|c|c|c|c|c|c|}
\hline & \multicolumn{2}{|c|}{$\begin{array}{l}\text { Pharmaceutical and Medicine } \\
\text { Manufacturing (3254) }\end{array}$} & \multicolumn{2}{|c|}{$\begin{array}{l}\text { Pharmaceutical Preparation } \\
\text { Manufacturing (325412) }\end{array}$} & \multicolumn{2}{|c|}{$\begin{array}{l}\text { Research \& Development in the Physical, } \\
\text { Engineering, and Life Sciences (54171) }\end{array}$} \\
\hline & (1) & $(2)$ & (3) & (4) & (5) & (6) \\
\hline \multicolumn{7}{|l|}{ Contemporaneous Effects } \\
\hline \multirow[t]{2}{*}{ Biotech Incentive } & 0.001 & & 0.000 & & 0.005 & \\
\hline & $(.003)$ & & $(.004)$ & & $(.003)$ & \\
\hline \multirow[t]{2}{*}{ R\&D User Cost } & $-0.033 * *$ & & $-0.034 *$ & & -0.006 & \\
\hline & $(.016)$ & & $(.020)$ & & $(.020)$ & \\
\hline \multicolumn{7}{|l|}{ Cumulative Effects (0-2 years) } \\
\hline \multirow[t]{2}{*}{ Biotech Incentive } & & -0.001 & & -0.003 & & 0.003 \\
\hline & & $(.002)$ & & $(.003)$ & & $(.003)$ \\
\hline \multirow[t]{2}{*}{ R\&D User Cost } & & $-0.035 * *$ & & -0.033 & & -0.008 \\
\hline & & $(.018)$ & & $(.027)$ & & $(.025)$ \\
\hline Percent Effect of Biotech Incentives & 0.077 & -0.076 & 0.047 & -0.265 & 0.513 & 0.341 \\
\hline Percent Effect of R\&D User Cost & 0.374 & 0.401 & 0.392 & 0.377 & 0.069 & 0.089 \\
\hline Sample Period & $1990-2007$ & $1990-2007$ & $1990-2007$ & 1990-2007 & 1990-2007 & $1990-2007$ \\
\hline Number of States & 43 & 43 & 37 & 37 & 40 & 40 \\
\hline Number of Observations & 618 & 555 & 438 & 395 & 670 & 590 \\
\hline
\end{tabular}

Notes: Regressions estimated via OLS. Standard errors based on Newey-West VC estimator with within-state AR(2) errors. For biotech incentives, the percent effect is defined as the ratio of the coefficient over the pre-adoption mean, holding constant R\&D tax credits. For R\&D user cost, is the effect of an increase in R\&D tax credits

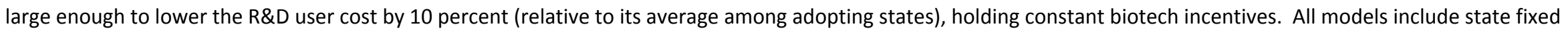
effects and year fixed effects. 
Table 9. The Effect of Incentives on Number of Establishments

\begin{tabular}{|c|c|c|c|c|c|c|}
\hline & \multicolumn{2}{|c|}{$\begin{array}{l}\text { Pharmaceutical and Medicine } \\
\text { Manufacturing (3254) }\end{array}$} & \multicolumn{2}{|c|}{$\begin{array}{l}\text { Pharmaceutical Preparation } \\
\text { Manufacturing (325412) }\end{array}$} & \multicolumn{2}{|c|}{$\begin{array}{l}\text { Research \& Development in the Physical, } \\
\text { Engineering, and Life Sciences (54171) }\end{array}$} \\
\hline & $(1)$ & $(2)$ & (3) & (4) & (5) & (6) \\
\hline \multicolumn{7}{|l|}{ Contemporaneous Effects } \\
\hline \multirow[t]{2}{*}{ Biotech Incentive } & 9.102 & & $5.541 *$ & & 113.541 & \\
\hline & (3.319) & & $(2.425)$ & & $(45.636)$ & \\
\hline \multirow[t]{2}{*}{ R\&D User Cost } & -9.812 & & -8.827 & & -333.870 & \\
\hline & $(10.920)$ & & $(8.961)$ & & (120.078) & \\
\hline \multicolumn{7}{|l|}{ Cumulative Effects ( 0 - 2 years) } \\
\hline \multirow[t]{2}{*}{ Biotech Incentive } & & $7.840 * *$ & & $4.775 *$ & & $105.524 * *$ \\
\hline & & (3.144) & & $(2.574)$ & & $(47.431)$ \\
\hline \multirow[t]{2}{*}{ R\&D User Cost } & & -9.663 & & -13.035 & & $-405.360 * * *$ \\
\hline & & $(11.918)$ & & $(12.964)$ & & $(142.180)$ \\
\hline Pre-Biotech-Incentive-Adoption Mean & \multicolumn{2}{|c|}{76.78} & \multicolumn{2}{|c|}{35.556} & \multicolumn{2}{|c|}{621.222} \\
\hline Pre-Credit-Adoption Mean & \multicolumn{2}{|c|}{47.08} & \multicolumn{2}{|c|}{23.260} & \multicolumn{2}{|c|}{281.929} \\
\hline Percent Effect of Biotech Incentives & 11.86 & 10.21 & 15.58 & 13.43 & 18.28 & 16.99 \\
\hline Percent Effect of R\&D User Cost & 2.400 & 2.363 & 4.370 & 6.453 & 13.636 & 16.556 \\
\hline Sample Period & 1990-2007 & 1990-2007 & 1990-2007 & 1990-2007 & 1990-2007 & 1990-2007 \\
\hline Number of States & 51 & 50 & 50 & 49 & 51 & 51 \\
\hline Number of Observations & 977 & 880 & 955 & 863 & 1020 & 918 \\
\hline
\end{tabular}

Notes: Regressions estimated via OLS. Standard errors based on Newey-West VC estimator with within-state AR(2) errors. For biotech incentives, the percent effect is

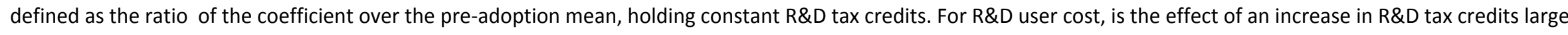
enough to lower the R\&D user cost by 10 percent (relative to its average among adopting states), holding constant biotech incentives. All models include state fixed effects and year fixed effects. 
Table 10. The Effect of Incentives on Patents

\begin{tabular}{|c|c|c|c|c|c|c|c|c|}
\hline \multirow[b]{3}{*}{ Contemporaneous Effects } & \multicolumn{2}{|c|}{ Patents } & \multicolumn{2}{|c|}{ Patents (Individual) } & \multicolumn{2}{|c|}{ Patents (Corporate) } & \multicolumn{2}{|c|}{ Patents (University) } \\
\hline & (1) & (2) & (3) & (4) & (5) & (6) & (7) & (8) \\
\hline & & & & & & & & \\
\hline \multirow[t]{2}{*}{ Biotech Incentive } & 36.469 & & 29.276 & & 5.607 & & 1.463 & \\
\hline & $(30.836)$ & & $(21.616)$ & & $(8.388)$ & & $(1.254)$ & \\
\hline \multirow[t]{2}{*}{ R\&D User Cost } & $-275.933 *$ & & -192.160 & & $-67.667 *$ & & -15.152 & \\
\hline & $(114.246)$ & & $(79.066)$ & & $(30.795)$ & & $(5.970)$ & \\
\hline \multicolumn{9}{|l|}{ Cumulative Effects (0-2 years) } \\
\hline \multirow[t]{2}{*}{ Biotech Incentive } & & 27.020 & & 24.577 & & 1.400 & & 1.030 \\
\hline & & $(29.990)$ & & $(20.999)$ & & $(8.503)$ & & $(1.265)$ \\
\hline \multirow[t]{2}{*}{ R\&D User Cost } & & $-269.134 * *$ & & $-185.172 * *$ & & $-70.328 * *$ & & $-13.045 * *$ \\
\hline & & $(131.251)$ & & $(90.765)$ & & $(35.660)$ & & $(6.589)$ \\
\hline Pre-Biotech-Incentive-Adoption Mean & \multicolumn{2}{|c|}{262.94} & \multicolumn{2}{|c|}{183.95} & \multicolumn{2}{|c|}{66.05} & \multicolumn{2}{|c|}{13.31} \\
\hline Pre-Credit-Adoption Mean & \multicolumn{2}{|c|}{114.11} & \multicolumn{2}{|c|}{79.53} & \multicolumn{2}{|c|}{31.67} & \multicolumn{2}{|c|}{6.42} \\
\hline Percent Effect of Biotech Incentives & 13.870 & 10.276 & 15.915 & 13.361 & 8.488 & 2.120 & 10.993 & 7.741 \\
\hline Percent Effect of R\&D User Cost & 27.844 & 27.158 & 27.821 & 26.809 & 24.603 & 25.570 & 27.181 & 23.402 \\
\hline Sample Period & $1990-2010$ & $1992-2010$ & 1990-2010 & $1992-2010$ & $1990-2010$ & $1992-2010$ & 1990-2010 & $1992-2010$ \\
\hline Number of Observations & 1071 & 969 & 1071 & 969 & 1071 & 969 & 1071 & 969 \\
\hline
\end{tabular}

Notes: Regressions estimated via OLS. Standard errors based on Newey-West VC estimator with within-state AR(2) errors. For biotech incentives, the percent effect is defined as the ratio of the coefficient over the pre-adoption mean, holding constant R\&D tax credits. For R\&D user cost, is the effect of an increase in R\&D tax credits large enough to lower the R\&D user cost by 10 percent (relative to its average among adopting states), holding constant biotech incentives. All models include state fixed effects and year fixed effects. 


$$
\text { Stars (95th percentile) New Stars (95th percentile) }
$$

Pharmaceutical and Medicine Manufacturing (3254)

PANEL A: Spatial Weighting Matrix based on interstate population flows.

Contemporaneous Effects

Biotech Incentive

$\begin{array}{lc}13.583 & 1.712 \\ (8.326) & (1.940) \\ -\mathbf{7 6 . 1 1 0} * * * & \mathbf{- 1 7 . 7 7 4} * * \\ (28.760) & (7.821)\end{array}$

R\&D User Cost

Spatial Lag

Biotech Incentive

R\&D User Cost

\section{$-19.147 *$}

(10.079)

$-244.358$

(215.649)

100.667

40.158

13.493

21.823

1990-2010

50

1050

Pre-Credit-Adoption Mean

Percent Effect of Biotech Incentives

Sample Period

Number of States

-3.717
$(3.034)$
-111.325
$(\mathbf{6 2 . 4 3 4 )}$
26.556
12.248
6.446
16.709
$990-2010$

$-3.717$

$1.325 *$

-

(3)

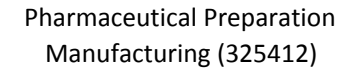

(4)

ing (325412)
Research \& Development in the

Physical, Engineering, and Life Sciences (54171)

istance between each pair of states.

PANEL B: Spatial Weighting Matrix based on inverse-distance between each pair of states.

Biotech Incentive

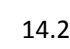

(8.948)

1.721
$(2.100)$

R\&D User Cost

$-76.448 * * *$

$-18.017 *$

(28.542)

(7.651)

Spatial Lag

Biotech Incentive

$$
\begin{array}{r}
-12.415 \\
(20.250)
\end{array}
$$

$-252.065$

R\&D User Cost

Pre-Biotech-Incentive-Adoption Mean

(238.878)

100.667

40.158

14.169

Percent Effect of Biotech Incentives

Percent Effect of R\&D User Cost

21.920

1990-2010

(5)

Sample Period

Number of States

Number of Observations

$1.235 *$
$(.631)$
$-7.538 * *$
$(3.606)$

$1.769 * *$
$(.711)$
$-7.959 *$
$(4.471)$

$3.990 * * *$

(1.439)

$-5.214$

(4.059)

\section{$-1.027$}

(.900)

18.356

(19.819)

8.043

7.698

15.352

11.275

1990-2010

37
777

1.798

$\begin{array}{rr}(.918) & (2.346) \\ 30.271 & -3.494\end{array}$

$\begin{array}{rr}(.918) & (2.346) \\ 30.271 & -3.494\end{array}$

(22.716) (33.226)

$5.792 \quad 21.701$

$6.495 \quad 10.611$

$30.549-18.387$

14.111

$1990-2010$

28

Notes: In panel A, the Spatial Weighting Matrix is based on interstate population flows. In palel B, the spatial Weighting Matrix based on inverse-distance between each pair of states. 
Appendix Table 1. Description of State Biotech Incentives

State

Maryland

Massachusettes

New Jersey

$\begin{array}{ll}\text { New Jersey } & 1996 \text { - present } \\ & \\ \text { Arkansas } & 2003 \text { - present }\end{array}$

2003 - present

1999 - present

Colorado

Washington

2004 - present

Maine

1997 - present

Missouri

$1999-2003$

Florida

2002 - present

North Carolina

1984 - present

California

\section{Credit Type}

Income Tax Credit for early-stage biotech companies

"Life Sciences Tax Incentive Program": Investment tax credit, special sales tax exemptions, refundable research tax credit

"Business Employment Incentive Program" (BEIP). Broad-based grant for job creation, with a lower job-creation qualifying threshold for biotech and "emerging high technology." Also provides financial assistance for companies in these sectors.

JCTC, Sales tax refunds, and R\&D Tax credits with higher subsidies for "targetted businesses," which consists of: (i) Advanced materials and manufacturing systems; (ii) Agriculture, food and environmental sciences; (iii) Biotechnology, bioengineering and life sciences; (iv) Information technology; (v) Transportation logistics; and (vi) Bio-based products."

Biotech Sales and Use Tax Refund

High Tech Business \& Organization Credit for R\&D Spending, Includes the "Biotechnology \& Medical Device Manufacturing Sales \& Use Tax Deferral/Waiver" Sales tax exemption on machinery, equipment, instruments, and supplies for biotech research

State \& local sales or use tax exemption for life sciences companies (which is just slightly broader than the sales and use tax exemptions available to most manufacturers)

Specialized incentives and tax credits, (more technically, the biomedical industry was reclassified as "high-impact", so that qualified companies could be eligible for the state's preexisting capital investment tax credits and the High Impact Performance Incentive (a JCTC-type program)

Has the North Carolina Biotechnology Center which make low interest loans to biotech start-ups.

2004 - present California Stem Cell Research and Cures Act, which provides biotech research grants 
Appendix Table 2. Estimates Conditional on Region and Division Trends

\begin{tabular}{|c|c|c|c|c|}
\hline \multirow{2}{*}{ Contemnoraneous Fffects } & \multicolumn{2}{|c|}{ Region Trends } & \multicolumn{2}{|c|}{ Division Trends } \\
\hline & \multirow[t]{2}{*}{ Biotech Incentive } & \multirow[t]{2}{*}{ R\&D User Cost } & \multirow[t]{2}{*}{ Biotech Incentive } & \multirow[t]{2}{*}{ R\&D User Cost } \\
\hline Contemporaneous Effects & & & & \\
\hline \multirow[t]{2}{*}{ Stars } & 13.174 & -73.117 & 9.043 & -50.335 \\
\hline & (7.663) & (30.817) & (6.524) & $(29.934)$ \\
\hline \multirow[t]{2}{*}{ New Stars } & 1.428 & -4.673 & 1.025 & -2.238 \\
\hline & $(.886)$ & (3.498) & $(.753)$ & $(3.547)$ \\
\hline \multirow[t]{2}{*}{ Employment - Pharmaceutical and Medicine Manufacturing (3254) } & 1075.857 & -9435.284 & 432.613 & -8904.278 \\
\hline & $(565.127)$ & (3754.774) & $(455.727)$ & $(3352.449)$ \\
\hline \multicolumn{5}{|l|}{ Employment - Pharmaceutical Preparation Manufacturing } \\
\hline \multirow[t]{2}{*}{$(325412)$} & 1353.251 & -9473.389 & 739.146 & -10285.490 \\
\hline & (645.549) & (4637.265) & $(544.011)$ & $(4262.766)$ \\
\hline \multicolumn{5}{|l|}{ Employment - Research \& Development in the Physical, } \\
\hline \multirow[t]{2}{*}{ Engineering, and Life Sciences (54171) } & 3672.225 & -3510.039 & 3252.809 & -303.420 \\
\hline & $(1363.094)$ & $(4290.760)$ & $(1219.043)$ & $(4326.328)$ \\
\hline \multirow[t]{2}{*}{ Wages - Pharmaceutical and Medicine Manufacturing (3254) } & 0.001 & -0.030 & 0.001 & -0.032 \\
\hline & $(.003)$ & $(.016)$ & $(.003)$ & $(.016)$ \\
\hline \multirow[t]{2}{*}{ Wages - Pharmaceutical Preparation Manufacturing (325412) } & 0.002 & -0.031 & 0.001 & -0.033 \\
\hline & $(.004)$ & $(.019)$ & $(.004)$ & $(.020)$ \\
\hline \multicolumn{5}{|l|}{ Wages - Research \& Development in the Physical, Engineering, and } \\
\hline \multirow[t]{2}{*}{ Life Sciences (54171) } & 0.006 & -0.001 & 0.006 & -0.004 \\
\hline & $(.003)$ & $(.020)$ & $(.003)$ & $(.020)$ \\
\hline \multicolumn{5}{|l|}{ Establishments - Pharmaceutical and Medicine Manufacturing } \\
\hline \multirow[t]{2}{*}{ (3254) } & 7.706 & -7.425 & 5.872 & 6.548 \\
\hline & $(2.825)$ & (11.111) & (2.220) & $(12.109)$ \\
\hline \multicolumn{5}{|l|}{ Establishments - Pharmaceutical Preparation Manufacturing } \\
\hline \multirow[t]{2}{*}{$(325412)$} & 4.385 & -10.182 & 3.011 & -11.234 \\
\hline & $(2.122)$ & (9.242) & (1.624) & $(8.968)$ \\
\hline \multicolumn{5}{|l|}{ Establishments - Research \& Development in the Physical, } \\
\hline \multirow[t]{2}{*}{ Engineering, and Life Sciences (54171) } & 104.825 & -319.254 & 96.439 & -231.389 \\
\hline & $(42.757)$ & $(123.663)$ & (36.592) & $(119.521)$ \\
\hline \multirow[t]{2}{*}{ Patents } & 32.862 & -256.727 & 20.083 & -178.617 \\
\hline & (28.534) & $(120.816)$ & (24.622) & $(115.070)$ \\
\hline
\end{tabular}

Notes: Regressions estimated via OLS. Standard errors based on Newey-West VC estimator with within-state AR(2) errors. There are 4 Census regions and 9 Census divisions. 
Appendix 3. R\&D Tax Credit Rate Replacing R\&D User Cost

\begin{tabular}{|c|c|c|c|c|c|}
\hline & $\begin{array}{l}\text { Stars (95th percentile) } \\
\text { (1) }\end{array}$ & $\begin{array}{l}\text { New Stars (95th } \\
\text { percentile) } \\
\text { (2) }\end{array}$ & $\begin{array}{l}\text { Pharmaceutical and } \\
\text { Medicine Manufacturing } \\
\text { (3254) } \\
\text { (3) }\end{array}$ & $\begin{array}{l}\text { Pharmaceutical Preparation } \\
\text { Manufacturing (325412) } \\
\text { (4) }\end{array}$ & $\begin{array}{l}\text { Research \& Development in } \\
\text { the Physical, Engineering, and } \\
\text { Life Sciences (54171) } \\
\text { (5) }\end{array}$ \\
\hline \multicolumn{6}{|l|}{ Contemporaneous Effects } \\
\hline Biotech Incentive & $\begin{array}{l}14.759 * \\
(8.405)\end{array}$ & $\begin{array}{l}1.662 * \\
(.967)\end{array}$ & $\begin{array}{l}1.301 * * \\
(.656)\end{array}$ & $\begin{array}{l}1.758 * * \\
(.738)\end{array}$ & $\begin{array}{l}3.928 * * * \\
(1.479)\end{array}$ \\
\hline R\&D User Cost & $\begin{array}{l}65.072 * * \\
(25.572)\end{array}$ & $\begin{array}{r}4.450 \\
(2.927)\end{array}$ & $\begin{array}{l}5.993 * * \\
(2.997)\end{array}$ & $\begin{array}{r}6.025 \\
(3.842)\end{array}$ & $\begin{array}{r}3.572 \\
(3.467)\end{array}$ \\
\hline Sample Period & $1990-2010$ & $1990-2010$ & $1990-2009$ & $1990-2009$ & $1990-2009$ \\
\hline Number of States & 51 & 51 & 38 & 28 & 47 \\
\hline Number of Observations & 1071 & 1071 & 798 & 588 & 987 \\
\hline
\end{tabular}

Notes: Employment in columns 3-5 is measured in thousands. Regressions estimated via OLS. Standard errors based on Newey-West VC estimator with within-state AR(2) errors. 
Appendix Table 4. Effect of Early Adoption on Star Scientists and Employment

\begin{tabular}{|c|c|c|c|c|c|}
\hline & $\begin{array}{l}\text { Stars (95th percentile) } \\
\text { (1) }\end{array}$ & $\begin{array}{l}\text { New Stars (95th } \\
\text { percentile) } \\
\text { (2) }\end{array}$ & $\begin{array}{l}\text { Pharmaceutical and } \\
\text { Medicine Manufacturing } \\
\text { (3254) } \\
\text { (3) }\end{array}$ & $\begin{array}{l}\text { Pharmaceutical Preparation } \\
\text { Manufacturing (325412) } \\
\text { (4) }\end{array}$ & $\begin{array}{l}\text { Research \& Development in } \\
\text { the Physical, Engineering, and } \\
\text { Life Sciences (54171) } \\
\text { (5) }\end{array}$ \\
\hline \multicolumn{6}{|l|}{ Contemporaneous Effects } \\
\hline Biotech Incentive & $\begin{array}{l}23.987 \\
(13.285)\end{array}$ & $\begin{array}{r}3.577 \\
(3.080)\end{array}$ & $\begin{array}{l}3.036 * * * \\
(1.004)\end{array}$ & $\begin{array}{l}3.110 * * * \\
(1.019)\end{array}$ & $\begin{array}{l}6.460 * * * \\
(2.180)\end{array}$ \\
\hline R\&D User Cost & $\begin{array}{l}-82.554 * * * \\
(29.979)\end{array}$ & $\begin{array}{l}-19.567 * * \\
(8.125)\end{array}$ & $\begin{array}{l}-8.621 * * \\
(3.450)\end{array}$ & $\begin{array}{l}-8.690 * * \\
(4.274)\end{array}$ & $\begin{array}{r}-6.882 \\
(4.245)\end{array}$ \\
\hline \multicolumn{6}{|l|}{ First4adopters*Incentive } \\
\hline Biotech Incentive & $\begin{array}{l}-24.761 * \\
(14.040)\end{array}$ & $\begin{array}{r}-4.449 \\
(3.319)\end{array}$ & $\begin{array}{l}-3.927 * * * \\
(1.049)\end{array}$ & $\begin{array}{l}-3.484 * * * \\
(1.054)\end{array}$ & $\begin{array}{l}-6.660 * * * \\
(2.262)\end{array}$ \\
\hline R\&D Tax Credit & $\begin{array}{r}46.141 \\
(40.038)\end{array}$ & $\begin{array}{r}17.031 \\
(12.525)\end{array}$ & $\begin{array}{c}-10.295 * \\
(5.360)\end{array}$ & $\begin{array}{c}-11.753 * \\
(6.180)\end{array}$ & $\begin{array}{r}3.899 \\
(4.154)\end{array}$ \\
\hline Pre-Biotech-Incentive-Adoption Mean & 100.667 & 26.556 & 8.043 & 5.792 & 21.701 \\
\hline Pre-Credit-Adoption Mean & 40.158 & 12.248 & 7.698 & 6.495 & 10.611 \\
\hline Percent Effect of Biotech Incentives & 23.828 & 13.469 & 37.743 & 53.698 & 29.771 \\
\hline Percent Effect of R\&D User Cost & 23.671 & 18.395 & 12.894 & 15.406 & 7.468 \\
\hline Sample Period & $1990-2010$ & $1990-2010$ & $1990-2009$ & $1990-2009$ & $1990-2009$ \\
\hline Number of States & 51 & 51 & 38 & 28 & 47 \\
\hline Number of Observations & 1071 & 1071 & 798 & 588 & 987 \\
\hline
\end{tabular}

Notes: Employment in columns 3-5 is measured in thousands. Regressions estimated via OLS. Standard errors based on Newey-West VC estimator with within-state AR(2) errors. 